\title{
Hafıza Mekânlarında Sanatın Bir İletişim ve Öğrenme Biçimi Olarak Kullanılması
}

\author{
Ceren Acun \\ Doktora Öğrencisi \\ Galatasaray Üniversitesi \\ Medya ve Iletișim Çalıșmaları \\ cerenacun04@gmail.com \\ ORCID: 0000-0002-2438-4788
}

\begin{abstract}
The Use of Art in Sites of Memory as a Way of Communication and Learning

This study deals with "sites of memory" such as "memory museums" and "counter-monuments" which evolved out of counter-memory movements after WWII, as human rights and identity politics of nation-states were brought into question. Sites of memory focus on the plurality of memory by bringing up narratives contradicting official history; for these places it is essential to build interactive learning environments. In this context, our study demonstrates that the use of artworks and artistic practices in sites of memory, creates communicative spaces. Sensory experiences acquired through art, reveal effective ways of learning; therefore, make contributions for empathizing with the neglected truths of the oppressed and to help dealing with difficult pasts.
\end{abstract}

keywords: Sites of memory, learning through art, relational aesthetics, communication, sensory experience 


\section{Résumé}

\section{L'utilisation de l'art dans les sites de mémoire comme moyen de communication et d'apprentissage}

Cette étude discute des "sites de mémoire", tels que les "musées de la mémoire" et les "contre-monuments" qui ont évolué à partir des mouvements de contre-mémoire après la Seconde Guerre Mondiale, à mesure que les droits de l'homme et les politiques identitaires des États-nations ont été introduits en question. En mettant l'accent sur la pluralité de la mémoire en évoquant des récits contredisant l'histoire officielle; pour ces lieux il est essentiel de créer des environnements d'apprentissage interactifs. Dans ce contexte, notre étude démontre que l'utilisation d'œuvres d'art et des pratiques artistiques dans des sites de mémoire, crée des espaces communicatives. Les expériences sensorielles acquises à travers l'art, révèlent des moyens d'apprentissage efficaces; faites donc des contributions pour sympathiser avec les vérités négligées des opprimés et pour aider à faire face à des passés difficiles.

mots-clés: Sites de mémoire, apprentissage par l'art, esthétique relationnelle, communication, expérience sensorielle

\section{Öz}

Bu çalışmada, resmi tarih anlatılarının karanlıkta bıraktığı yerel anlatıları yeniden gün yüzüne çıkarma niyetiyle hareket eden "hafıza mekânlarına" odaklanarak, hafıza müzelerinden karşı-anıtlara, bu tür mekânlarda sanatsal pratiklerin geçmişten öğrenme yöntemi olarak nasıl kullanıldığını ele alıyoruz. Iktidarların hafıza üzerinde kurduğu denetimin araçları olan geleneksel müzelerin ve kahramanlık anıtlarının aksine, II. Dünya Savaşı sonrası başlayan karşı-hafıza hareketlerinden doğmuş olan günümüz hafıza mekânları; yaratıcı bilgi edinme ve hatırlama biçimlerine dayanarak toplumlar arası diyaloğu teşvik eden, hafızanın çoklu yapısını etkileşimsel öğrenme ortamları sağlayarak ön plana çıkarmak isteyen oluşumlardır. Bu bağlamda ilişkili yaklaşım ve tartışmaları takip ederek ilerlediğimiz çalışmamızda, söz konusu etkileşimsel öğrenme ortamlarının, hafıza mekânlarında öncelikle sanatla edinilen duyusal deneyimler aracılığıyla meydana geldiğini söylüyoruz. Dünyadaki ve Türkiye'deki örnekleri üzerinden incelediğimiz bu mekânlarda yer alan sanat yapıtlarının ve başvurulan çeşitli sanat pratiklerinin, unutulmuş hakikatlerin anlaşılabilmesi ve öğrenilebilmesi açısından üstlendiği başat rolleri gündeme getirmeyi amaçlıyoruz.

anahtar kelimeler: Hafıza mekânları, sanatla öğrenme, ilişkisel sanat, iletişim, duyusal deneyim 


\section{Giriş}

Jorge Luis Borges bir öyküsünde ${ }^{1}$, geçirdiği bir kaza yüzünden felç olup yürüyemeyen, ancak bu olayla birlikte olağanüstü bir hatırlama yetisi kazanan Ireneo Funes'in başından geçenleri anlatır. Funes'in biz sıradan insanlarınkiyle kıyas kabul etmeyecek denli keskin hafızası hiçbir şeyi unutmadığı gibi, her şeyi en ince ayrıntısına kadar kayda alan sesli ve görüntülü bir cihaz gibi çalışmaktadır. Ne var ki, bu ayrıntılar tüm yoğunluğu ve ağırlığıyla hafızasını doldurmaya devam ederken, düşünme eyleminden de giderek yoksun kalır Funes. Öyle ki, artık düşünemediği için ne rüya görebilmekte ne de hayal kurabilmektedir. Bu durum onu, katlanılmaz biçimde ayrıntılı bir dünyanın yapayalnız izleyicisi haline getirir. Bize göre, bu kısa hikâyede Borges'in vurgulamak istediği, esas olarak, hafıza ve düşünme arasındaki bağın kopmasıyla ortaya çıkan bir tür düşünsel felç. Başka deyişle, kendi içinde son derece yaratıcı anımsama, unutma, düzenleme ve tefekkür gibi süreçlerle çalışan hafızanın, salt ayrıntıların yarattığı bir mahrumiyetle büsbütün kuşatımış olması.

Aynı düşünsel felç, hiçbir sorgulamaya mahal vermeden öğretilen ve hatta ezberletilen geçmişin bilgisinin, bireysel ya da kolektif hafızalarımızı esir almasıyla da gerçekleşmektedir. Bu mesele en açık haliyle, devletlerin ulusal tarihlerini ve kimliklerini oluşturmak için hatırlama ve unutma eylemleri üzerinde kurdukları denetim alanında kendini gösterir. Ders kitapları, kitle iletişim araçları, müzeler, anıtlar ve anma törenleri, ulusal birliğini kurmaya ve muhafaza etmeye çalışan her siyasi iktidarın elinde inşa ve filtreleme aygıtlarına dönüşerek sadece anlatılması "uygun" görülen bir geçmişi sunarlar. Bununla birlikte, farklı kültürel toplulukların hafızası, makro anlatıların dışında bırakıırken, sistemli baskı ve unutturma eylemleri, ulus-devletlerin kimlik politikalarının da temelini oluşturur.

Diğer taraftan, geçtiğimiz yüzyılın ortalarından itibaren bu politikalar, ulus-devlet ve küreselleşme geriliminde kimlik krizlerini tetikleyerek tarih yazımı ve toplumsal hafıza gibi konular etrafında yeni tartışmaları başlatmıştır. Süregelen tartışmalarda hatıllama ve unutma pratikleri, çoğunlukla ideolojik araçlar olarak mercek altına alınırken, kuşku götürmez bir gerçeklik payına sahip bu yaklaşım, bir yandan da başka bir gerçeği gözden kaçırır: hafıza, bütünüyle resmi tarihin alanı içinde değerlendirilebilecek bir olgu değildir. Ve bu türden bir hegemonya analizi, hafızanın farkIı toplumsal koşullara direnç gösterebilmesini sağlayan anlam iletme kapasitesini açıklamakta yetersiz kalmaktadır. Aynı indirgeyici yaklaşım, çağımızda hafızaya dair artan ilgiyi de yine yalnızca modernitenin çıkmazlarıyla tetiklenen kimlik krizleriyle açıklamaya çalışır; bastııımış toplulukların kimliklerini geri kazanmak için patolojik bir biçimde yeni anma kültürlerine sarıldığını ileri sürer.

Oysa burada göz ardı edilen en mühim mesele, 1980'lerle birlikte "bellek patlaması" diye adlandırılan bu durumun, kimlik krizlerinin yanında, bireysel ve

1 Yazarın Bellek Funes isimli öyküsü. F. Özgüven (Çev.). Ficciones: Hayaller ve Hikâyeler içinde (s.131-147) İstanbul: İletişim Yayınları, 2013. 
toplumsal travmaları iyileştirici güce sahip "karşı-hafıza" hareketlerini de ortaya çıkarmasıdır. Son kırk yılda bilgi ve iletişim teknolojilerinde yaşanan gelişmeler, bilginin kolay ve hızlı bir şekilde dolaşıma girmesini sağlarken, elbette çarpıtma ve suistimalleri beraberinde getirmektedir. Ancak, bilgi edinme kaynaklarının çeşitlenmesi, yerel ve ulusal bellekler arasındaki gizli çelişkilere bir görünürlük kazandırarak resmi anlatılara direnme yollarını da açmaktadır.

Biz de bu makalede, karşı-hafıza hareketleriyle birebir ilişkili olduğunu düşündüğümüz "hafıza mekânlarına" odaklanacağız. Kısaca açıklamak gerekirse, bizim burada konu edindiğimiz hafıza mekânları, Pierre Nora'nın (2006) tanımladığı haliyle ulusal ölçekte bir gruba bağlıı̆ıın sembolü olan geleneksel müze ve anıtlardan ziyade, yenilikçi ve yaratıcı hatırlama pratikleri ve bilgi edinme yöntemleriyle ile ön plana çıkan hafıza müzeleri ve karşı-anıtlardır. Hafıza mekânları, öncelikle, farklı ülkelerdeki örnekleriyle ele alacağımız gibi, diyaloğu ve karşııklı anlayışı teşvik ederek zor geçmişlerle yüzleşme yolunda çözüm üretmeye çalışan yerlerdir. Bunların gerçekleşebilmesi adına gereken ilk adım ise, ziyaretçinin anlatılan geçmişle bir bağ kurmasını sağlamaktır. Dolayısıyla, hafıza mekânları için görsel, işitsel vb. duyuları uyaran etkileşimsel öğrenme ortamları yaratmak büyük önem taşır.

Bu bağlamda yazıda, hafıza mekânlarında söz konusu etkileşimsel ortamın oluşmasında başat rol üstlendiğine inandığımız sanat yapıtlarının, duyusal deneyimlerle yeni öğrenme biçimlerine nasıl yön verdiğine ve yaratıcı hafıza pratiklerine nasıl katkıda bulunduğuna eğileceğiz. Buradan hareketle, ilk olarak hatırlama ve unutmaya yönelik pratiklerin değişiminin tarihsel sürecine daha yakından bakacağız ve ardından sanat yapıtlarının bu mekânlarda hafızanın aktarımı açısından işlevlerini anlayabilmek adına şu sorularla ilerleyeceğiz: Hafıza mekânlarında sanat yapıtlarının kullanımı, nasıl bir iletişimsel ve etkileşimsel alan yaratmaktadır? Sanatla edinilen duyusal deneyimler, ziyaretçiler için bir öğrenme biçimine dönüşebilir mi? Sanat, hakikatlerin aydınlatılması ve geçmişle yüzleşmek adına bir ifade aracı olabilir mi? Sanatla öğrenme deneyimleri, zor geçmişlerin anlaşılabilmesi için ne tür katkılar sunar?

\section{Dönüşen Anma Pratikleri ve Hafıza Mekânları}

Hafıza, yalnızca geçmişin izleri aracılığıyla gerçekleşen bir yineleme işlemi değil, oldukça karmaşık bir şekilde çalışan tanıma, özdeşleştirme ve kavramlaştırma sürecidir ve bu süreç olmaksızın, bir kültür inşasından söz edilmez (Cassirer,1980, s. 54). Hafızanın adeta bir kurucu unsur ve dinamo görevi üstlendiği kültür yoluyla insan; geçmiş, şimdi ve gelecek tasarılarını birbirine bağladığı bir zamansal sistem yaratarak, bireysel yaşam süresini aşan ve sonraki nesillere ulaşan bir anlam üretimi gerçekleştirir. Kültür, bu bakımdan bir toplumun genetik olarak değil, semboller üzerinden aktarılan belleğidir (Assmann, 2008, s. 97).

Aleida Assmann, hafıza üzerine düşünürken, en başta unutma eylemi ile başlamamız gerektiğini söyler. İnsan belleğinin dinamikleri hatıllama ve unutma 
arasındaki sürekli etkileşimden meydana geldiği için, bir şeyleri hatılamak adına diğerlerinin unutulması gerekir. Dolayısıyla, unutma süreci hem bireysel hem toplumsal hayatımızın doğal bir parçasıdır. Bunun yanı sıra, tüm kültürel ve toplumsal pratiklerimize daha yakından baktığımızda, aktif ve pasif olarak iki unutma sürecinden söz etmek mümkündür. Aktif unutma, tahrip etme ve yok etme gibi eylemlerle imlenirken, unutmanın pasif hali ise, kaybetme, gizleme, inmal etme, terk etme veya bir şeyi geride bırakma gibi kasıtlı olmayan eylemlerle ilgilidir. Bu tip durumlarda nesneler fiziksel olarak imha edilmezler. Daha ziyade, değer ve kullanım çerçevelerinden düştükleri gibi, daha sonra yeniden keşfedilebilirler (2008, ss. 97-98).

Eğer unutmanın bireysel ve kültürel hayatın normal bir parçası olduğunu kabul edersek, o halde esas olarak hatırlama eylemi istisnai bir durum olarak karşımıza çıkar. Çünkü hatırlama eylemi, gündelik hayatımızın kültürel, politik ve toplumsal alanlarında her zaman çeşitli kısıtlamalarla sınılandırılan da bir eylemdir. Hatta bu eylem, çoğu zaman belli tedbirler eşliğinde gerçekleşir. Söz konusu tedbirler, kimi zaman karşımıza kültürel kurumlar olarak çıkarlar (Assmann, 2008, s. 98).

Müzeler, bu kurumların önde gelen örneklerinden biridir. Yukarıda kısaca değindiğimiz üzere, müzeler, özellikle 19. yüzyıl ile başlayan süreçte modern ulus-devletlerin resmi tarihlerini inşa etmesinde ve buna bağlı olarak ortak bir kültürün, ulus kimliğinin ve belleğinin benimsetilmesinde başat bir rol üstlenmişlerdir. Benedict Anderson'ın belirttiği gibi, müzeler bu dönemde, "hayali cemaatlerin" iddia ettikleri ezeli varoluşlarını ve ulus düşüncesini kurumsallaştırabilmek adına harita ve nüfus sayımı ile birlikte intiyaç duyduğu üç unsurdan biri olarak görülmüştür (1995, s.182). Illerleme fırtınasının payandası olarak kabul edilen bu mekânlar, ulusal ve evrenselci anlamda kültürel meşruluğun yerleşmesinin ana planlarını sağlarken, bilim dallarına göre ayrılmış arşivleri ve koleksiyonlarıyla, dışlamalara ve marjinalleştirmelere olduğu kadar; olumlu sistematik düzenlemelere de dayanan dış ve iç sınırlar çizerek, Batı uygarlığının kimliğinin tanımlanmasını sağlamıştır (Huyssen,1999, s. 25).

Müzeler, ulus-devlet ideolojisi doğrultusunda hafızanın aktif boyutunu ve kolektif kimlik algısını biçimlendirirler. Bu açıdan tıpkı unutma gibi, hatırlamanın da aktif ve pasif bir tarafı vardır. Aleida Assmann, bu aktif olarak dolaşıma sokulan, yapılandırıcı hafızayı "kanon", daha pasif şekilde depolanan ve muhafaza edilen hafızayı ise "arşiv" olarak nitelendirir. Aktif boyutuyla hafıza, her zaman bir seçme işlemi içinde, toplumların kültürel sermayesini üretir, onaylar ve bir döngü içinde tutar. Bu kanonlaştırma işlemidir. Özellikle, totaliter rejimlerde Orwell'in 1984 adlı romanında gösterdiği gibi, geçmişten kalan bilgi kırıntıları değiştirilmesi veya ortadan kaldırıması gereken unsurlardır; çünkü kanıt değeri taşıyan bu şeylerin yöneticilerin güçlerini dayandırdığı resmi tarihi parçalama ya da olası karşı hareketleri başlatabilme yetisi vardır. Öte yandan toplumların anımsama kaynağı olan arşivlerin işlevi ise, aktif hafızanın indirgeyici ve kısıtlayıcı tutumuna karşı bir denge oluşturmaktır. Unutulmuş olanı koruyan, ikincil bir kaynak-hafıza oluşturur. Bir 
anlamda artık göz önünde olmasına gereksinim duyulmayan şeylerin ayrılığı bir kayıp eşya bürosu gibi çalışır. Bu tarihsel arşivler bize kendimizi zamanda konumlandırma fırsatı verir; geçmişe dönük tarihsel bilincimizi ve bilgimizi muhakeme edebilmemizi sağlar (Assmann, 2008, ss. 98-105).

Hemen burada Orwell'ın ana karakteri Winston Smith'i ve çalıştığı “Gerçek Bakanlığı" kurumunu aklımıza getirebiliriz. Winston, her türlü belgenin değiştirildiği ve "bellek deliği" adı verilen hava boşluklarına atılarak yok edildiği bu kurumun arşivcisidir. Ancak bir süre sonra herkesten saklanan gerçekleri unutmamak adına ve özgürlügünü kazanmak umuduyla gizlice bir günlük tutmaya başlar. Arşivde gözlerden uzak kalan gerçekler, Winston'ın içinde adeta bir direnişin ateşini fitiller. Dayatılan hafızanın karşısında kendi hatırladıklarıyla, etrafında olup biten her şeye dair bir hakikat arayışının çıkış noktasına doğru sürüklenir Winston.

Diğer yandan 1984, tam da İkinci Dünya Savaşı́nın sona ermesinden üç yıl sonra, Insan Hakları Evrensel Bildirgesi'nin yayınladığı 1948 senesinde yazıımıştır. Jay Winter'a göre hem George Orwell'ın (ki kendisi bir insan hakları aktivisti olarak da bilinmektedir) romanı hem de bildirge, bize hatırlamanın bir insan hakkı olduğunu anlatmak ister. İçinde açıkça belirtilmese bile, yine de dünyanın her yerinde savaşların, özgürlüklere getirilen sınılamaların ve hak ihlallerinin kurbanı olanların sesini duyurmak ve onların varlıklarını anımsatmak amacı taşımasının, bu bildirgeyi bir hafıza belgesi yaptığını söyler (2012, ss. ii-xi).

Genel anlamda, İkinci Dünya Savaşı sonrası dönem; insan haklarının, bilginin demokratik ve şeffaf paylaşımının, savaşlar ve soykırımlar gibi trajedilerin bireyler ve toplumlar üzerindeki travmatik etkilerinin, geçmişi hatırlama ve unutma biçimlerinin tüm dünyada sorgulanmaya başlamasında bir dönüm noktası olmuştur. Henüz ilkinin yaraları sarımamışken gerçekleşen bu savaş, Auschwitz ve Hiroşima gibi insanlık tarihinde büyük bir utanç ve kara bir leke bırakacak olayları hazırlamıştır. Dolayısıyla, böyle bir felaketin ardından gelen süreç oldukça çalkantılı sosyal, kültürel ve de politik dönüşümlere sahne olmuştur. Örneğin 1960'ların düşünsel ve toplumsal hareketleriyle birlikte hâkim tarih anlayışı sarsılmaya başlarken, tarihçiler arasında hafızanın siyasal iktidarlarca bir tahakküm aracı olarak kullanıldığı yönünde görüşler kendini gösterir. Bu görüşler, özellikle Michel Foucault'nun bilgi ve iktidar arasındaki ilişkiyi sorgulayan çığır açıcı çalışmalarıyla belirginlik kazanır. Hafızanın denetim altına alınmasıyla, toplumların eylemlerinin de denetim altına alınabileceğine (1975, s. 25) dikkat çeken düşünür, diğer yandan da hafızanın iktidarın çatlakların sızabilecek bir direniş aracı olarak, bir "karşı-hafıza" (1977, s. 153) niteliğinde kullanılabileceğini söyler.

Belleğin dönüştürücü gücünün (hem olumlu hem olumsuz taraflarıyla) yavaş yavaş ayırdına varıldığı bu süreç, 1980 'lerin son yarısından itibaren küreselleşme ve kitle iletişiminin büyük bir hızla gelişmesiyle çok daha farklı boyutlara taşınarak hatırlama ve unutma dinamiklerinde de küresel çapta farklılıklar yarat-

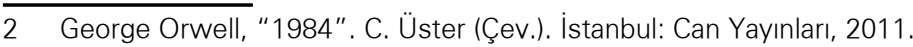


mıştır. Assmann ve Conrad'a göre, daha önceden zor geçmişlerle hesaplaşma gibi meseleler devletlerin tekelindeyken, küreselleşmenin getirdiği yeni koşullarla ortaya çıkan sivil toplum kuruluşları, uluslararası ağlar, hakikat ve uzlaşma komisyonları gibi oluşumlar, yeni politik ve kültürel aktörler olarak bu alanda söz sahibi olmaya başlamış; geçmişte işlenen suçları aydınlatma, gerçekleri ve failleri bulma çabalarıyla toplumsal hafızaya yepyeni bir yön çizmişlerdir (2010, ss. 1-3).

Devletlerin neyin nasıl ve ne kadar hatırlanması konusundaki yerleşmiş baskı ve manipülasyonları, bu sayede eski gücünü ve etkisini kaybetmiştir. Bu durumu, Soğuk Savaş döneminin bitimine dek uygulanmış olan "affetme ve unutma" politikalarının değişimiyle örneklendirmek mümkündür. 1945 sonrasında bu politik tutum, gerek Batı Almanya toplumunun tesis edilmesi gerekse de Sovyet Rusya'ya karşı birlik olunması amacıyla Avrupa genelinde benimsenmiştir. Bu nedenle, çok kısa bir süreliğine varlık gösteren Nürnberg Mahkemeleri'nde, yargılanan çoğu Nazi yetkilisine ve destekçisine itibarlarının iade edilmesi kararına, Fransa ve Ingiltere gibi devletler itiraz etmemiştir. Hatta suçların üzerini örtme ve unutma istenci o kadar ileri gitmiştir ki, o sıralar kendini göstermeye başlamış olan muhalif sesler karşısında, dönemin önde gelen siyasi figürlerinden Winston Churchill, savaşın sorumlularına gerekli cezaların verildiğini ve artık "geçmişle hesaplaşma sürecinin bitmesi gerektiğini" açıkça ifade etmiştir (Assmann, 2012, s. 58).

Ne var ki bu yaklaşımlar, yukarıda sözünü ettiğimiz gelişmelerle giderek sürdürülemez hale gelmiş ve Batı Almanya'daki (Avrupa'daki) söylemlerin paradigması faillerden kurbanların deneyimlerine ve tanıklıklarına kaymaya başlamıştır. Bunlara ilaveten, özellikle 1990'ların ilk yarısıyla beraber Sovyetler Birliği'nin ve Doğu Bloku'nun dağılmasıyla, Latin Amerika'da askerî diktatörlüklerin çözülmesiyle, Güney Afrika'da ırkçı rejimin çökmesiyle, geçmişte işlenen ağır suçlar ve hak ihlalleriyle nasıl uğraşılacağı, büsbütün bir evrenselleşme sürecine girmiştir (Sancar, 2007, s. 14). Tüm bu süreçler, rejim değişikliklerinin politik ve toplumsal çelişkileri çözmekte tek başına yeterli olmadığı gerçeğine dikkati çekerken, güçlerini arşiv ve tanıklık çalışmalarından alan sivil toplum kuruluşlarının ve hakikat komisyonlarının ve genel anlamda hafıza çalışmalarının önemini ortaya koyar (Assmann ve Shortt, 2012, ss. 4-10).

Artık unutmanın bir çözüm olmadığı ve geçmişi hatırlayarak travmatik anılarla yüzleşmenin, iyileşme yolundaki en doğru adım olduğu eskisinden daha yaygın biçimde kabul görmektedir. Aslen 1960'lardan beri gelişerek bugünkü halini alan yeni hatırlama pratikleri aynı zamanda müzeler gibi belleği denetim altına alma niyetiyle inşa edilen kurumlarda büyük değişimler yaşanmasının önü açarak, bugün "hafıza mekânları" dediğimiz yerlerin en baştan, yeni anlam ve işlevlerle tanımlanmasını sağlamıştır. Sözgelimi, tıpkı müzeler gibi, siyasal iktidarların geçmiş ve gelecek tahayyüllerini yansıttığı anıtlar ve bu anıtlar etrafındaki anma yöntemleri ciddi manada bir yapısökümüne uğramıştır diyebiliriz. 
Buradan hareketle Jay Winter'a yeniden kulak verdiğimizde, yazar, 20. yüzyııın ilk büyük savaşından sonra yapılan anıtların yalnızca kahramanlıkları anma amaçlı ziyaret edilmediğini, özellikle sonraki zamanlarda, yıkıma ve kayıplara sebep olanları lanetlemek için de ziyaret edildiğini söyler. Ayrıca, ağır silahlar ve insanlar arasındaki dengesiz mücadeleyi perdelemek adına Ortaçağın kahraman ve aziz mertebesine yükseltilmiş savaşçılarının imgelerinin kullanıldığı bu ilk dönem yapıtlarının, yerlerini giderek, kaybın hüznünü ya da hepten bir "yokluğu ve yokoluşu" anlatmak için yapılan "negatif anıtlara" ve "karşı-anıtlara", çoğunlukla da figüratif olmayan bir forma bıraktığını belirtir (2015, ss. 329-335).

Bir sonraki bölümde de göreceğimiz üzere, burada Andreas Huyssen'in (1999) öne sürdüğü gibi çeşitli hegemonik alanların içinden ya da Michel de Certeau'nun (2009) deyişiyle düşünürsek iktidarın stratejik mekânlarından filizlenen ve daha tabandan gelen taktiksel yeni anma mekânları söz konusudur. Bu mekânlar; kimi zaman hafıza müzeleri olarak, kimi zaman yukarıda sözünü ettiğimiz "karşı-anıtlar" olarak ve kimi zaman da bir toplama kampının, eski bir direniş alanının ya da sürgün ve savaş gibi trajediler sonucu terk edilmek zorunda kalmış eski bir yaşam alanının bir hafıza mekânına dönüşmesi olarak karşımıza çıkarlar. Ancak hepsi aynı düşünce ve niyetle varlık gösteren yerlerdir: belleğin dönüştürücü gücüne dayanarak, resmi anlatılar ve sessizleştirilmiş toplulukların anlatıları arasındaki çelişkileri açığa çıkarmak ve karanlıkta bırakılmış hakikatleri göstermek; bunu yaparken mağdurları kurbanlaştırma yoluna gitmeden, onların deneyimlerini ve tanıklıklarını naklederek ziyaretçilerle empatik bir bağ oluşturabilmek; ve bu sayede, yaşanan trajedilerin içinden aynı zamanda umut ve direnişin de doğabileceğini göstermek. Bunlarla beraber, girişte bahsettiğimiz gibi, tüm bu süreçlerde hafıza mekânları, söz konusu hedeflerini uygulayabilmek için, sanatın öğrenmeye ve empatiye olanak veren deneyimsel alanından beslenir. Şimdi biz de sanatın bu konuda üstlendiği role daha yakından bakacağız.

\section{Tefekkür Mekânları: Hafıza Mekânlarında Sanat Deneyimi ile Öğrenme}

Hafıza, resmi tarihin içinde sindirilmeye çalışılsa da bütünüyle denetim altına alınabilecek bir olgu değildir. Ve iktidarların, ulusal anlatıların benimsenmesi ve yerel anlatıların unutulması için gösterdiği çaba, Freud'un sözünü ettiği bastırılanın geri dönüşü 3 ihtimaliyle her zaman karşı karşıyadır. Hafızanın esas anlamda çoğul olan yapısı, bu nedenle her zaman özgül grupların kimliği ve resmi tarihin kesişiminde durur. Kolektif hafıza kuramının yaratıcısı Maurice Halbwachs, bu bakımdan, resmi tarihin temellendiği ulusal ve evrensel tek bir geçmiş anlayışının aksine, hafızanın hem çoğul hem de bireysel olabilen yapısından söz eder. Başka deyişle, birden fazla hafıza vardır çünkü topluluklar sayıca çeşitlidir (2018, s. 102).

3 Freud "Tekinsizlik" (The Uncanny, 1919) başlıklı makalesinde, bilinçaltına itilen kaygı ve korkuların gün yüzüne çıkmasının yarattığı tekinsiz duygulanımlardan söz eder. Bastıılan duygular, bir "ötekiye" yansıtııı; ancak bu hem korkutucu derecede tuhaf ve yabancı hem de şaşırtıcı biçimde tanıdık öteki, kişiye sürekli musallat olur $(1919: 1,21)$. https://web.mit.edu/allanmc/www/freud1.pdf 
Hafıza mekânları da, Halbwachs'ın bu düşüncesine paralel bir biçimde, her şeyden önce tekillik yerine çoğulluğu teşvik eden yerlerdir. Bu bakımdan, farklı anlamların, seslerin ve hikâyelerin dünyasıdır. Bizi uzak olduğumuz ya da hepten habersiz olduğumuz dünyalara yaklaştırılar. Makro anlatılar yerine, marjinalleştirilmiş ve ötekileştirilmiş toplulukların unutturulan anlatılarını, temelde etkileşimsel yollar kullanarak aktarırken, izleyicilerin de adeta birer iz sürücü gibi hareket edip gizli saklı kalmış gerçekleri keşfetmelerini ve onlarla empati kurmalarını isterler. Dolayısıyla sahip oldukları bilgi, belge ve nesneleri aynı zamanda bir duygusal yatırım aracı gibi değerlendirerek, olabildiğince yenilikçi ve katılımcı yollarla ziyaretçileriyle paylaşırlar. Bu sayede geçmişte yaşanmış sosyal adaletsizliklere, zulümlere ve tüm eşitsiz uygulamalara dikkati çekerek ve en önemlisi üzeri örtülen gerçeklere dair sorular sorulmasını sağlayarak, kendilerini alternatif bir öğrenme mekânı olarak konumlandııılar.

Söz konusu katılımın ve etkileşimsel ortamın yaratabilmesi adına, sanat yapıtları ve yaratıcı sergileme tekniklerine başvurulması bu mekânlar için vazgeçilmezdir. Hatta sanatın duyusal deneyimi ön plana çıkaran yönü sayesinde bu öğrenme biçimleri görsel, işitsel vb. yollarla desteklenir. Burada Jennifer Hansen-Glucklich'in ${ }^{4}$ (2014, s. 102) çağdaş müzelerle ilgili tespitinden faydalanarak, hafıza mekânlarının da, eski müzeler gibi yalnızca görme duyusuna hitap ederek tasarlanmış yerler olmadıklarını ve diğer duyuları sanatın iletişimsel gücünden destek alarak harekete geçiren yerler söylemek gerekir. Böylelikle izleyiciler, hem mekânla hem de karşılaştıkları anlatılarla zihinsel ve bedensel bir bütünleşme sürecine girerler.

Konuya dair örneklere geçmeden önce burada bir parantez açarak, bellek ve sanat arasında kadim bir iletişimsel bağ olduğunu hatırlamak gerekir. Bellek tanrıçası Mynemosyne'nin tüm güzel sanatların ve ilham perilerinin (Musalar) anası olduğu efsanesi bir yana, iki olguyu birbirine bağlayan esas nokta, insanın en eski çağlardan bu yana çevresiyle kurduğu ilişkinin gelişim biçimidir. İnsan, duyuları yoluyla yaşadığı tüm deneyimleri belleğinde depoladığı gibi, bu duyusal deneyimleri işleyen ve anlamlandırmaya gayret eden bir canlıdır. Kendi dünyasını da belleğindeki bu birikimleri dışa vurarak inşa eder. Sanat da her zaman bu dünyanın en önde gelen ifade aracl; diğer bir deyişle düşüncelerin ve duyguların yaratıcı bir şekilde cisimleştiği alan olmuştur. Bu sebeplerden ötürü, bu iki olgu hep iç içe bir ilişki içinde olagelmiştir.

Bunlarla birlikte, Nicolas Bourriaud'nun (2005) deyişiyle, sanatın bir karşılaşma ve temas biçimi olması, hafıza mekânlarındaki hatıllama ve geçmişten öğrenme pratikleri üzerinde belirleyici roldedir. Çünkü sanat, yine Bourriaud'yu takip edecek olursak, daima farklı seviyelerde ilişkisel, yani toplumsallı̆ı̆ bir etmeni ve bir diyalog kurucu olmuştur. Ve imgeler potansiyel olarak bağ kurabilme yetisine

4 Jennifer Hansen-Glücklich, "Holocaust Memory Reframed" adlı kitabında, Martin Jay'in "görme öncelikli rejimler" (scopic regimes) teriminden yola çıkarak, geleneksel müzelerin Kartezyen perspektif mantığı ile yapılandığını öne sürer. Görmenin önceliği, düşünce tarihi içinde, İlkçağ felsefesinden bu yana büyük oranda benimsenmiş bir kuramdır. 
sahip oldukları için, tüm göstergeler ve işaretler empati ve paylaşım üretir veya bakan kişiyle muhakkak bir bağ üretir. Dolayısıyla, bir sergi sırasında kıpırtısız, cansız formlar söz konusu olsa bile, anında bir tartışmanın doğması olasılığı ortaya çıkar (2005, ss. 24-27).

Özetle sanatı, kendine özgü bir toplumsallığın üretildiği alan olarak tanımlayan Bourriaud, bu noktada uzamın kent tarafından sunulan "karşılaşma durumlarının" bütünü içindeki statüsünün ne olduğuna bakmak kalıyor (2005, s. 24), der. Biz de buradan yola çıkarak öncelikle mimar ve sanatçı Daniel Libeskind tarafından yapılan Berlin Yahudi Müzesi'ne bakarak, konuyu örneklemeye çalışacağız. Bir önceki bölümde kısaca değindiğimiz gibi, Yahudi Soykırımı sonrasında yapılan hafıza mekânları (toplama ve imha kamplarının yanı sıra, soykırım öncesi Yahudilerin yaşadıkları yerler), savaşta ölenleri yad etmek için yapılan anıtlar gibi, artık kurbanların ölümünü yücelterek yapılan anıtlar olarak yapılamazdı. Bu nedenle, felaketin bir "hiç" uğruna gerçekleştiğini göstermek ve hiçin ifadesinin zorluğunun üstesinden gelebilmek için farklı formlara ve metaforlara başvurulmuştu. İşte Libeskind'in tasarladığı Yahudi Müzesi de öncelikle bir "yapı" olarak bunun bir örneğidir. Bu yapı deforme bir Davud Yıldızı'na veya taş ve camdan bir şimşeğe benzer (Winter, 2015, s. 337).

Görsel 1. Berlin Yahudi Müzesi (Kaynak: https://libeskind.com/ work/jewish-museum-berlin/)

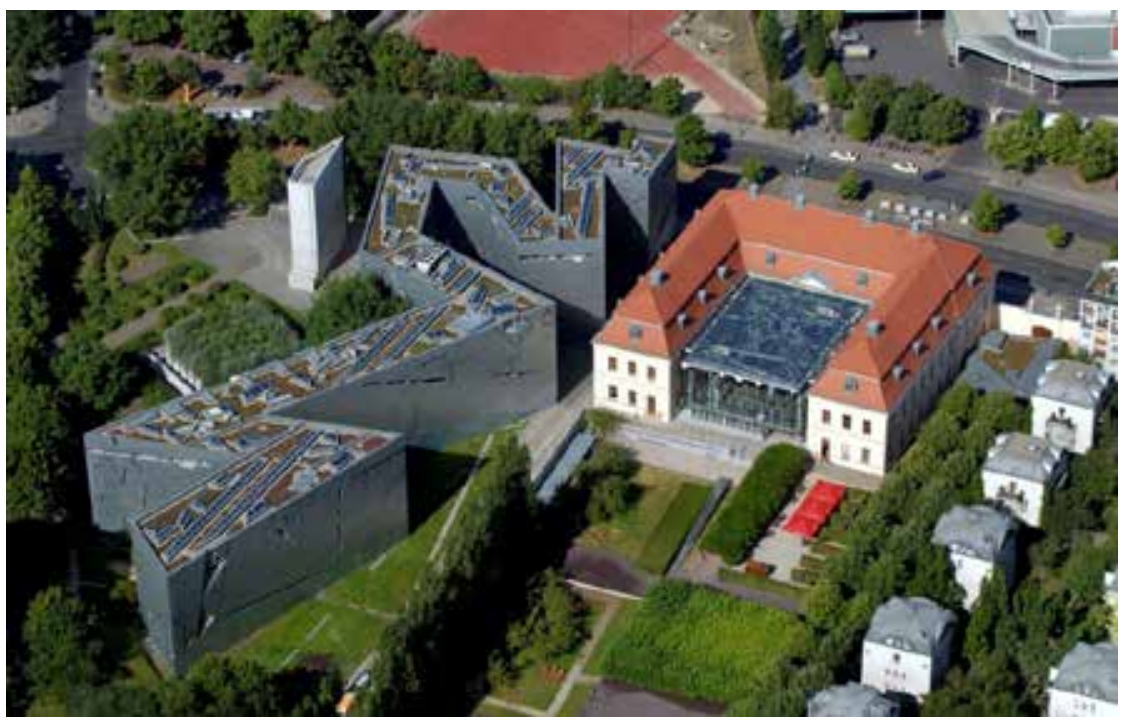

Parlak dış yüzey boyunca uzanan ve yıldızı oluşturan çatlaklar, kesintili pencere çerçeveleridir ve pürüzsüz malzemenin üzerindeki bu görünümleriyle, Libeskind'e ilham veren Arnold Schoenberg'in atonal müziğinin karakteristik özelliğine benzer bir "uyumsuzluk" sunarlar. Eleştirmen Michaela Giebelhausen bu 
bakımdan, müzenin mimarisinin sadece bir dış kabuktan ibaret olmadığını, aynı zamanda ziyaretçilerin algıma koşulları üzerinde hem kavramsal hem de fiziksel olarak belirleyici bir rol oynadığını dile getirir (akt.Hansen-Glucklich, 2014, s. 29). James Young da müzeye dair yazdığı bir incelemede, mekânın içinde boylu boyunca uzanan boşlukların yapısı ve anlamı üzerinde durarak, bu boşluk çizgilerinin geçtiği her yeri kasıtlı bir biçimde ihlal edecek şekilde düşünüldüğünü söyler. Örneğin odalar ve salonlar parçalayıcı kesiklerle şekilsiz anomalilere dönüşürken, bazıları hiçbir şeyi tutamayacak kadar küçük, bazıları ise içinde duran herhangi bir şeyi tutabilecek kadar eğik hale gelir (2000, s. 20).

Libeskind için, binanın omurgasını ve ana aksını oluşturan boşlukların böyle cisimleşmesi, bir yokluğun dışavurumudur; yani Berlin Yahudilerinin şehirden bir bütün silinip gitmesinin gözle görülür boşluğunun. Bir zamanlar kentin sosyal, kültürel hayatının büyük bir parçası olmuş bir topluluktan geriye kalan en somut hatıradır belki de (Young, 2000, s. 21). Kenti, Aldo Rossi'nin tanımlamasıyla "bir topluluğun kolektif belleğinin yuvalandığı mekân" olarak düşündüğümüzde, soykırım sonrası Berlin'in bozulan ve değişen topografyasında ve hafızasında meydana gelen boşluklar, müzenin dayandığı boşluk fikrini daha da anlamlı kılar (Hansen-Glucklich, 2014, ss. 31-39).

İçeride gezilmeye başlandığı anda ise, ilk olarak merakla duyuları harekete geçiren boşluklar, aynı zamanda bir tefekkür hali de yaratırlar. Örneğin yapının zemin katındaki Bellek Boşluğu adlı alan ve sanatçı Menashe Kadishman'ın burada bulunan Shalekhet ${ }^{5}$ (Düşen Yapraklar) adındaki enstalasyonu, tam da böyle anları elverişli kılar. Her biri çığlık atıyormuşçasına ağzı açık suratlara benzeyen, 10.000 'in üzerinde, irili ufaklı yuvarlak demir plakadan oluşan yapıt, soykırım mağdurlarının yaşadıkları acıyı temsil eder. İçeri giren ziyaretçiler, bu boş alanın zeminini kaplayan enstalasyonun üzerinde yürüyebilmekte ve en başta bu dokunsal deneyimle, aktarılmak istenen duygulara temas edebilmektedir.

Görsel 2. Berlin Yahudi Müzesi, Galeriler Görsel 3. "Bellek Boşluğu" ve "Shaleket"

(Kaynak: https://libeskind.com/work/jewish-museum-berlin/)
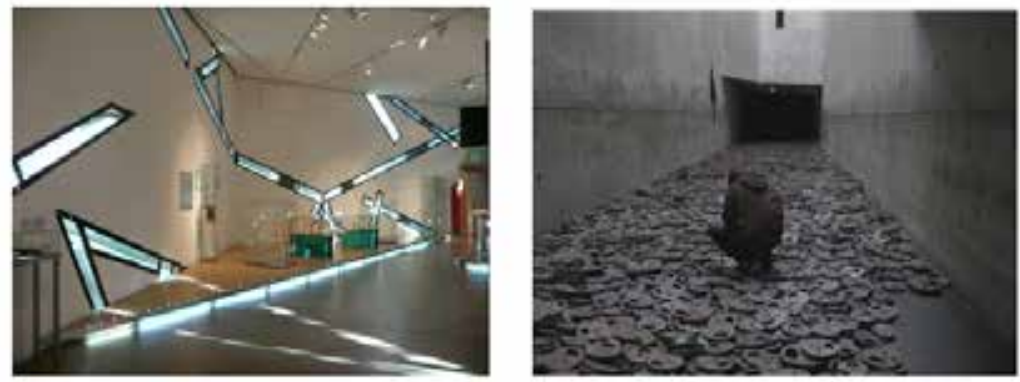

$\overline{5}$ Berlin Yahudi Müzesi https://www.jmberlin.de/en/shalekhet-fallen-leaves 
Müze, sanatın ilişkisel boyutu sayesinde, Almanya'nın kendi tarihiyle yüzleşmesi yönünde eğitici bir görev üstlenir ve iletmek istediği bilgiyi didaktik bir söylem içine oturmadan, yaratıcı küratöryel pratikleriyle iletir. Sözgelimi, sergilenen fotoğrafların, mektupların ya da türlü ev eşyalarının kimlere ait olduğu, bu kişisel nesnelerin bu zamana nasıl ulaşabildikleri, hikâyesel bir anlatımla ön plana çıkarıı. Ziyaretçilerini, etkin katılımcılar olarak konumlandırmaya çalışan müze, aynı zamanda çeşitli hafızalaştırma çalışmaları içeren atölyeler düzenleyerek, hayal gücünü etkinleştiren yeni hatırlama pratiklerini teşvik eder. Belleksizliğin üstesinden gelebilmek adına, özellikle çocukların ve gençlerin ilgisini çekecek etkinliklere sıkça yer verir. Hatta kimi zaman öğrencilerin sanatsal üretimlerini de dâhil ettiği sergiler ${ }^{6}$ düzenler.

Bunlarla birlikte, Buchenwald, Auschwitz veya Sachsenhausen gibi geçmişin ağır insanlık suçlarının işlendiği Nazi toplama kampları, bugün umudu ve mücadeleyi simgeleyen birer hafıza mekânı olarak varlıklarını sürdürmektedir. Hafızanın aktarımasına, geçmişle yüzleşmeye ve yaşananlarla bir bağ kurulabilmesine zemin hazırlamak için bu mekânlarda da sanat yapıtlarına, sanat atölyelerine başvurulmaktadır. Örneğin Buchenwald Anma Merkezi'nde, 1990'ların başından itibaren sanat yapıtları sergilenmeye başlamış ve ilerleyen yıllarda bunlar kalıcı sergilere dönüştürülmüştür. Bunlardan biri de, iki yüz kadar resim, çizim, fotoğraf, heykel, kolaj ve çeşitli enstalasyondan oluşan "Hayatta Kalmanın Yolları: Tanıklık, Sanat Yapıtı, Görsel Hafıza" ismindeki sergidir. Sergi ile ilgili dikkat çekici olan taraf, kamptaki tutukluların, soykııımdan kurtulanların ve de günümüz sanatçılarının eserlerinin bir arada sergileniyor olmasıdır. Ziyaretçilere, kampta yaşananların yarattığı travmalarla başa çıkabilmenin nasıl olabileceğini keşfettirmek isterler. Kendisi de bir zamanlar kampın esirlerinden olan ünlü Polonyalı tiyatro yönetmeni Józef Szajna'nın "Reminiscences" adlı enstalasyonu da burada yer almaktadır. Venedik Bienali'nde de sergilenen bu çalışma, esaret haline odaklanarak, kapatıma duygusunu yansıtan güçlü bir anlatıma sahiptir (Sujo, 200, s. 110).

Görsel 4. Józef Szajna, "Reminiscences", Buchenwald (Kaynak: https://www.buchenwald.de/47/date/2019/08/27/tag-desoffenen-denkmals-2019/ )

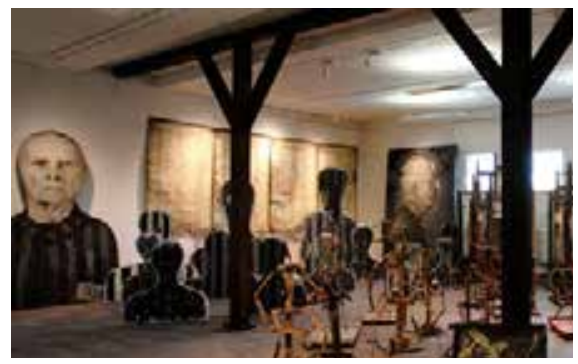

6 Berlin Yahudi Müzesi https://www.jmberlin.de/en/exhibition-a-is-for-jewish

7 https://www.buchenwald.de/en/1455/,http://auschwitz.org/en/museum/historical-collection/ works-of-art/, https://www.sachsenhausen-sbg.de/en/educational-programs/extended-seminars-and-projects/ 
Buchenwald, geçmişi sanatla anlamlandırıp yorumlayabilmeleri adına, gençler için bir merkez olma yönündeki çalışmalara da ağırlık vermektedir. Bunun için kurulan "Gençlik Merkezi"8 adlı alanda, sanatsal fikirlerin yaratıcı bir şekilde gerçekleştirilebilmesi için gençlere gerekli malzemelerin de sağlandığı pek çok atölye düzenlemektedir. Çalışmalardan birinde, katılımcılardan anma alanındaki görsel ya da işitsel deneyimlerini yansıtan işler üretmeleri istenir. Bu yöntem, gençleri bu tarihi mekânın hafızası ve kamptaki hayat üzerine düşünmeye sevk ederken, bir yandan da söz konusu meselelerle ilgili daha kalıcı bir merak ve keşif duygusu uyandırmayı amaçlar. Benzer bir eğitim programı Sachsenhausen Anma Merkezi'nde ${ }^{9}$ de uygulanmaktadır. Sanatsal deneyimin bölgenin tarihine ve yaşananlara daha bağımsız ve önyargısız bir bakış açısı sunabileceği düşüncesiyle hareket edilen Sachsenhausen'da, atölyelerin yanı sıra sanat deneyimine dair eğitsel seminerlere de yer verilmektedir. Yapılan açıklamalarda söylendiği gibi, anma alanını ziyaret etmek, kelimelerle anlatıması kolay olmayan hisleri, algıları ve izlenimleri doğurabildiği için, tüm bu sürecin anlamlandırılıp, ifade edilmesi adına bu tür faaliyetler son derece gerekli görülmektedir. Bu bağlamda, atölyelerde, çizgi romanlardan iğne deliği kameralarla çekilmiş fotoğraflara, heykellerden ses kolajlarına ve şiirlerden kısa öykülere kadar üretilen çeşitli işler, katılımcılar için hem bir ifade olanağı yaratır hem de bu işler üzerine soruların sorulmasıyla, birlikte düşünme ve tartışma ortamı doğmuş olur.

Görsel 5. Sachsenhausen Anma Merkezi, Sanat Atölyesi Atölyesi (Kaynak: https://www.sachsenhausen-sbg.de/)

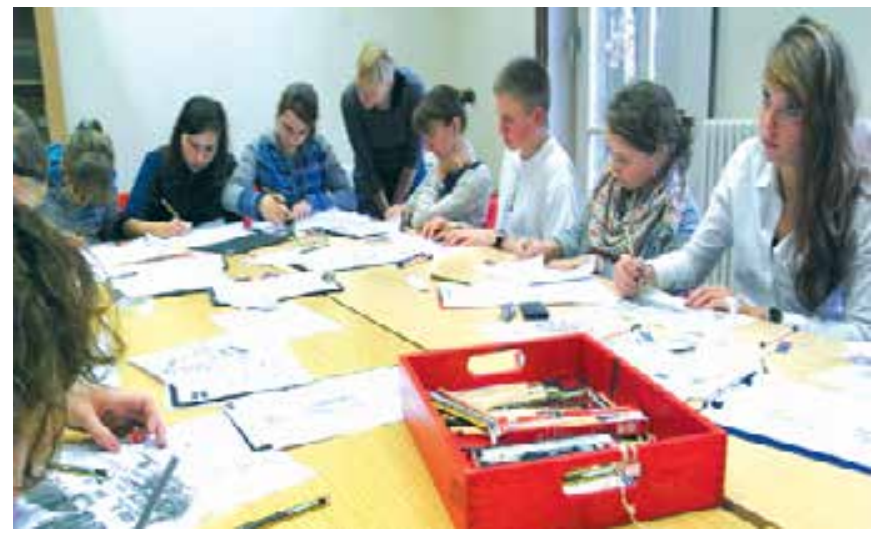

Konumuzla ilgili emsal oluşturan hafıza mekânlarından biri de Güney Afrika'nın Cape Town şehrinde bulunan District Six (Altıncı Bölge) Müzesi. Müzenin ismini aldığı Altıncı Bölge, 1966'da Apartheid rejiminin aldığı kararla, sadece "beyazların" yaşayabileceği bir mahalle olarak ilan edilip "beyaz olmayan" sakinlerince boşaltılmak zorunda bırakılana dek, işçi sınıfının, sanatçıların, yazarların, müzisyenlerin yaşadığı oldukça canlı bir mahalledir. Bu karar neticesinde ise, altmış bin insan

8 https://www.buchenwald.de/en/1378/,

9 https://www.sachsenhausen-sbg.de/en/educational-programs/extended-seminars-and-projects/ 
buradan kovularak, evleri ve neredeyse tüm yaşam alanları buldozerle yerle bir edilmiştir. Ancak uygulamalar karşısında giderek güçlenen bir direniş meydana gelmiş ve Apartheid rejiminin 1994'te son bulmasına kadar, insanlar mahalleleri için mücadele etmeye devam etmişlerdir. İşte müze, ırkçılık karşısında yaşam haklarının talep edildiği bu hareketlerin içinden doğmuştur (Layne, 2008, ss. 53-55).

Altıncı Bölge'yi ayakta tutabilmek için yerel halkın girişimleriyle 1994'te kurulan müze, Güney Afrika'da ve tüm dünyada yaşanan ayrımcı şiddetin ve baskının karşısında "en güçlü silahın hafıza" olduğu düşüncesi üzerine temellenir. Dolayısıyla, bu sivil girişimin ilk amacı, Altıncı Bölge'nin kozmopolit geçmişine odaklanarak, Apartheid döneminde bölgeye karşı yürütülen kara propagandayla oluşan ön yargıların, çarpıtılmış gerçeklerin üzerini örttüğü hakikatleri, unutulan hikâyeler vasıtasıyla gün yüzüne çıkarmak olmuştur. Böyle bir yaklaşım, ayrımcılık nedeniyle birbirlerinden kopuk yaşayan insanlar arasındaki ilişkileri onarıp güçlendirmenin de yegâne yolu olarak görülür. Bunlarla birlikte, geçen yıllar içinde bu amaca yönelik çalışmalar meyvelerini vermeye başlamış ve müze bugün, toplumsal adalete dair tartışmaların, sözlü tarih çalışmalarının ve yaratıcı sanatsal faaliyetlerin yapıldığı dinamik bir kamusal alana dönüşmüştür (Marstine, 2006, s. 30).

Bütün bu gelişmelerde, belleğin sanatla olan iş birliği ise neredeyse biçimlendirici bir rol üstlenmiş, bölge halkının kendi geçmişiyle yeniden bağ kurmasını sağlamıştır. Denilebilir ki, District Six Müzesi, gerçek anlamda sanatın hayatla iç içe geçtiği bir mekândır. Bunun en açık örneğini, "Streets" (Sokaklar) adlı ilk serginin oluşum sürecinde ve sonrasında yarattığı etkiyle görmek mümkündür. Kurucuların anlattıklarına bakılırsa, ilk başlarda müze ve sergiler için koleksiyon oluşturma arayışları sürerken, eski bir devlet çalışanın Altıncı Bölge'nin yıkımdan önceki sokak tabelalarını yirmi yıldır evinin bodrumunda sakladığı haberine ulaşmaları, bugüne kadar devam eden büyük bir iyileşme ve etkileşim sürecinin başlangıcı olmuş (Layne, 2008, s. 58).

Apartheid rejiminde başlayan yıkımlarda, sokakların ismi de toptan değiştirildiği için, yöneticiler tabelaların geçmişle bağ kuran hafıza nesneleri olarak sergide kullanılmasına karar vermişler. Serginin de ismi böylelikle bulunmuş. Sonrasında ise çoğu eski mahalle sakini olan sanatçılarla ortak bir çalışma yapılarak, sergi alanının zemini, bölgenin dönüşümden önceki halini gösteren bir haritayla boydan boya kaplanmıs. Sanatçılar harita üzerine çeşitli çizimler yapmışlar, şiirler eklemişler. Sergi açıldığında ise müthiş bir ilgi görmüş; eski sakinler haritanın üzerinde kendi sokaklarını, evlerini bulup işaretlemeye ve isimlerini yazmaya başlamışlar. Otobüs duraklarından pazar alanlarına, okullarından eğlence mekânlarına kadar her yeri, kendilerini adeta yeniden mahallede görünür kılarcasına haritada işaretlemişler. Bir çeşit sihir gibi işleyen bu süreç, Altıncı Bölge'ye ilişkin belleğin birden yeniden hayat bulmasını sağlamış. Örneğin yaşlı bir adam, elinde kendi adresinin yazdığı eski bir kartpostal getirerek, onu haritaya asmalarını istemiş. Harita bugün de aynı şekilde müzede dururken, insanlar müzeyi ziyaret ederek geçmişe gömülen şeylerin peşine düşmeye ve kendi hikâyelerini paylaşmaya devam etmekte- 
dirler. Hatta sergiyle ortaya çıkan bir gelişme de, eski oturulan yerler üzerinde hak taleplerine dair bir sürecin de başlamış olmasıdır (Layne,2 008, s. 59).

Görsel 6. District Six Müzesi, Cape Town Güney Afrika (Kaynak: https://www.districtsix.co.za/)

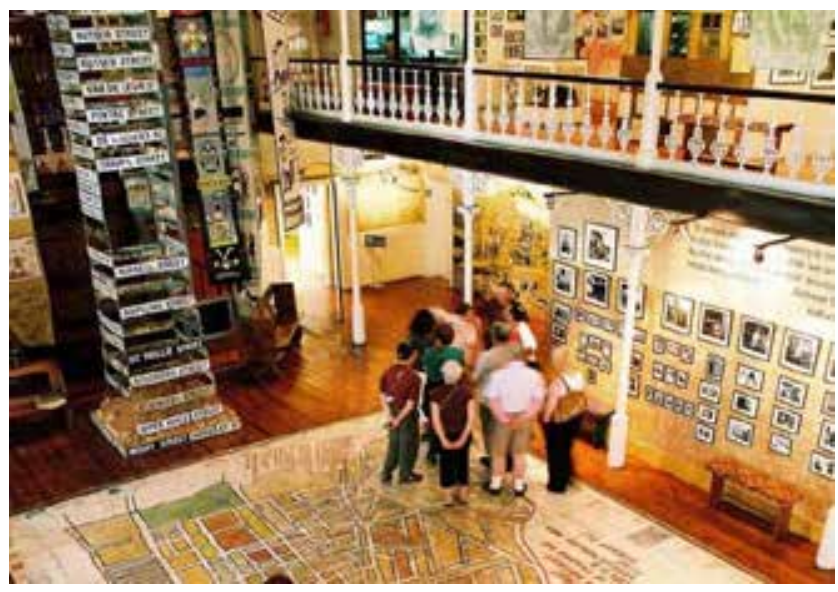

Özetle, sanat deneyiminin iletişimsel süreçlerin itici gücü olduğu bu serüven, yeni toplumsal ve kültürel hareketler için bir çıkış noktası oluşturmuştur. Geçmişe ilişkin yeni düşünme biçimlerini ve öğrenme yollarını mümkün kıldığı için, sanatın yarattığı deneyimsel alan, hafıza müzeleri için güçlü bir kaynaktır. Ayrıca, sanat ve arşivsel araştırmalar arasındaki etkileşimden doğan iş birliklerinin de bu alana katkısı da büyüktür. Dolayısıyla sanat yapıtlarının yanı sıra, hafıza müzelerinde, örneğin otobiyografik özelliğe sahip nesnelerin yaratıcı yollarla sergilenmesi, ziyaretçilerin geçmişle ilişki kurabilmesi adına vazgeçilmez bir stratejidir. Buchenwald Anma Merkezi, gençlerle birlikte yürüttüğü arkeolojik kazı atölyesi ${ }^{10}$ ile bu konuyu özgün bir yolla ele alır. Kazı çalışmalarında gençler, kamp mahkûmlarının kişisel eşyalarının ortaya çıkarılmasına ve ardından kayıt altına alınıp sergilenmesi sürecine bilfiil katııırlar. Bu yöntemle, nesnelerin hikâyesine daha yakından temas etmiş olurlar.

Kişisel eşyalar, içerdikleri anlamlarla her zaman ilgi çekici olmuşlardır. Hatta Appadurai'den ödünç alacak olursak, "bir sosyal yaşamları olan nesneler" (2013, s. 5) olarak tasavvur edilmişlerdir. Çünkü hem geçmişte kendilerine yüklenen anlamlarla hem de tanıklık ettikleri olaylarla büyük bir çağrıştırıcı ve anıştırıcı güç kazanırlar. İşte müzelerin için vazgeçilmez unsurlar oluşları da buradan ileri gelir. Sözgelimi, Berlin Yahudi Müzesi de sergilediği nesnelerin yanında, "Nesne Günleri" adı altında bir atölye düzenleyerek, gündelik eşyaların hafızalaştırma çalışmalarındaki yerini de anlatmayı hedefler.

10 https://www.buchenwald.de/en/1377/ 
Geçmişte çeşitli trajedilerin mağduru olmuş kimselerin tanıklıklarına başvurulması ve bunların görsel-işitsel kayıtlarının ziyaretçilerle buluşturulması da bütünsel bir anlama ve öğrenme sürecini teşvik eder. Bu nedenle, hafıza müzeleri farklı mekânsal ve sanatsal pratiklerden geniş ölçüde yararlanarak, bu kayıtlardaki anlatısallığı daha etkin bir halde sunmaya gayret ederler. "Video-testimony" (video tanıklık) adıyla bilinen bu yöntem, Yahudi Soykırımı sonrası kaybolmaya başlayan kuşakların belleğini koruyabilmek ve sonraki kuşaklara aktarabilmek amacıyla geliştirilmiştir. Kaybolan dünyalara ışık tutabilecek nitelikteki kayıtlar önemli bir diyalog ve empati aracı olabilmektedirler.

Konuyu gerek Marianne Hirsch'ün "post-hafıza" terimi gerekse de Alison Landsberg'in "protez-hafıza" terimiyle biraz daha açabiliriz. Hirsch, travmatik geçmişlere sahip ailelerde ilk ve sonraki kuşaklar arasında anlatılar ve imgeler yoluyla bir hafıza aktarımı gerçekleştiğini ve bunun sonucunda genç kuşakların hiç yaşamadıkları olayları sanki kendi deneyimleriymişçesine içselleştirdiğini söyler (1997, s. 22). Aile bağı, Hirsch'ün post-hafıza olarak tanımladığı bu hafızanın çıkış noktasını oluştursa da, içselleştirme hali, kendi aile geçmişinde böyle hikâyeler olmayan kimselerde de meydana gelebilmektedir. Hirsch'e göre bu durum, bir tür sahiplenme yoluyla geçmişe tanıklık etmektir (2001, s.10; 2012, s. 35). Landsberg ise, kişinin kendisine ait olmayan geçmişleri empati kurarak sahiplenme sürecinin, medya teknolojilerindeki ilerlemelerle birebir ilişkili olduğunu ileri sürer. Bu açıdan, internet, sinema, televizyon gibi mecraların yanı sıra, müzelerin multimedya araçlarını kullanarak yarattığı etkileşimsel ortamların rolünü gündeme getirir. Tüm diğer iletişim mecraları gibi müzeler de, Landsberg'in deyişiyle, yapay bir uzuv gibi iş görerek protez bir hafıza oluştururlar. Videolar, fotoğraflar ve sanat yapıtları, bu hafızanın araçları olarak, çok farklı empatik süreçleri beslerler. Bu şekilde, biyolojik veya kültürel bir bağ gerekmeksizin, insanlar geçmişte yaşanan belli olaylara dair bir hafıza edinirler (2004, ss. 1-9).

Ayrıca Landsberg, soykırım gibi ağır trajedileri salt mantıksal bir çizgisellikte anlatmanın, yaşananların boyutunun kavranabilmesi bakımından yeterli olmayacağı inancındadır. Bu sebeple "deneysel müzeler" kategorisinde değerlendirdiği hafıza müzelerinin, video-tanıklıklarını, gazetelerden makale parçalarını, başka yazılı belgeleri ve fotoğrafları bir araya getirerek, basit bir doğrusallıkta ilerlemeyen güçlü anlatıları ortaya çıkarttıklarını belirtir. Tüm bu deneysel uygulamaların ise, esasında hatırlama pratiklerini ve bilgiyi edinme biçimlerini değiştirdiğini ve bunlara bağılı olarak da "öteki" ile kurduğumuz ilişkideki yerleşik bakış açılarımız veya ön yargılarımız üzerinde de kırılmalar yarattığını söyler (2004, s. 131).

Diğer taraftan hafıza mekânlarının, son otuz yılda giderek artış göstermesini oldukça kuşkucu ve hatta kötümser bir yaklaşımla karşılayan görüşler de mevcuttur. Huyssen'e göre, bu görüşler, kültürümüzün ölümcül bir hafıza yitimine yakalandığı yakınmasıyla beraber, derinleşen bir bunalım duygusunu dile getirirler (1999, s. 11). Aslında bir önceki yüzyıl başında egemen olan hatıllama pratikleri çerçevesinde değerlendirilen bu durum, Nora'nın ifade ettiği şekilde, tüm hafıza mekânlarının 
ve anma kültürlerinin varoluş nedenlerini, artık "hafıza diye bir şeyin kendiliğinden olmadığı" (2006, s. 23) düşüncesine dayanarak açıklar. Nora bu mekânların, koruduğu şeyler tehlikede oldukları için, inşa edildiklerini ve günümüz toplumlarının bütünüyle tutucu bir inanç ile arşivsel bir üretkenliğe bağımlı yaşadığı dile getirirken, bu duruma biçtiği rolü ne derece patolojik bir seviyeye taşıdığını anlayabiliriz.

Bir başka olumsuz yaklaşım da, Althusserci bakış açısıyla, bu tür mekânları yalnızca egemen sınıfın meşrulaştırma ve egemenlik gereksinimlerine hizmet etmekle sınırlı bir ideolojik devlet aygıtı olarak değerlendirir. Sözgelimi, Baudrillard ve Jeudy gibi düşünürler, "müze çılgınlığı" olarak adlandırdıkları bu durumla, müzeleştirmeyi çağın en hastalıklı sorunlarından biri olarak görürler. Özellikle Baudrillard, simülasyonların yaygınlık kazanması dolayısıyla, kültürün can çekişme noktasına geldiğini ve müzelerin de, televizyon gibi, buna katkı sağladığını savunur. Huyssen'e bakılırsa, bu görüş, her ne kadar müze uygulamalarının aşırıya vardırılmış Avrupa merkezciliğine karşı cesur bir polemiğe girişse de, saldırdığı şeyin yörüngesinden kurtulmayı pek başaramaz. Üstelik, gizliden gizliye kıyametçi bir arzu içinde, bastııımış ya da marjinalleştirilmiş geçmişleri gözden geçirme yönündeki yaşamsal girişimlerin hiçbirini tanımadığı gibi, alternatif müze etkinlikleri yaratmaya yönelik çeşitli girişimleri de tanıyamaz (1999, ss. 28-47).

Son tahlilde, Huyysen, söz konusu yaklaşımların hiçbirinin bize kültürümüzü kuşatan anımsama arzularını açıklayacak gereçleri sağlayamadığını ve hafızaya ilişkin saplantılarımızın esasında, yaşam alanımızı oldukça belirgin biçimlerde değiştiren hızlı teknik süreçlere karşı bir tepki oluşturma işlevi gördüğünü ileri sürer. Bu noktada, yine kendisinin "bellek patlaması" olarak nitelediği durumu, bir anlamda "potansiyel olarak sağlıklı bir mücadele işareti" olarak sayabileceğimizi dile getirir. Aynı doğrultuda ilerleyerek, hafıza mekânlarının da ideolojik sınılları aşan yeniden doğuşların alanları olarak işlev görebileceği sonucuna varır (1999, ss.18-28).

Buraya kadar örneklerini incelediğimiz hafıza mekânları da, Huyssen'in belirttiği şekilde, ideolojik sınırları aşan hafıza pratikleri üzerine temellenir. Bir önceki bölümde kısaca sözünü ettiğimiz üzere, anıtlar tıpkı bu deneysel müzeler gibi, geçtiğimiz yüzyılın ortalarından bu zamana önemli dönüşüm süreçlerinden geçmiştir. Örneğin, Almanya'nın Yahudi sorunuyla yüzleşme(me)ye dair tutumu, 1980'lerin sonundan itibaren pek çok sanatçı tarafından ele alınmış ve eski anılların didaktik mantığının sorgulanması ile bu dönemde birçok karşı anıt üretilmiştir. Neticede faşizme karşı yapılacak bir anıt, aynı zamanda anıt mantığının, gerçeği gölgeleyen demogojik katılığına ve izleyicisini sadece edilgen bir alıııya indirgeyen yaklaşımına da karşı olmalıdır. Jochen Gerz ve Esther Shalev'in 1986'da Hamburg'da yaptığı "Faşizme Karşı Anıt" ismini taşıyan çalışma, bunun iyi bir örneğidir. On iki metre yüksekliğinde, ince bir kurşun tabaka ile kaplı ve içi boş bir alüminyum sütun olarak tasarlanan anıt, insanlar üzerine isimlerini ve diğer istedikleri şeyleri yazıp çizdikçe giderek oturduğu zeminin içine doğru batmaya başlamış. 1994 senesinde büsbütün ortadan kaybolduğunda, sanatçılar, geçmişin ağır yükünün de sonunda toprağa karışığını umduklarını söylemişler. Buradaki amaç her şey- 
den önce, insanları uysal bir kabullenişten çıkararak, kışkırtıcı bir sonsuz yok oluş durumuna tanıklık ve ortaklık etmelerini sağlamaktır (Young, 1992, ss. 271-276).

Görsel 7 ve 8. Jochen Gerz ve Esther Shalev, “Faşizme Karşı

Anıt", Hamburg

(Kaynak: https://www.shalev-gerz.net/portfolio/monument-againstfascism/)
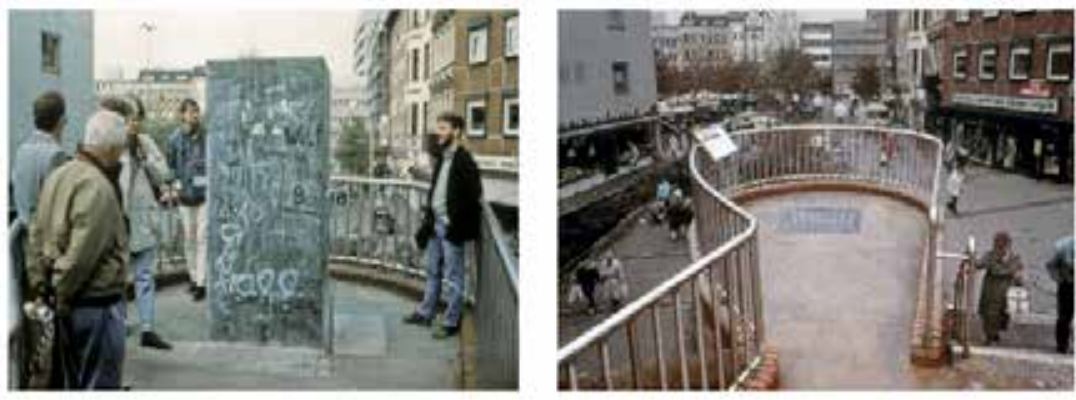

Yaklaşık aynı dönemlerde, sanatçı Horst Hoheisel'ın Almanya'nın Kassel şehri için yaptığı Aschrott Çeşmesi (Aschrottbrunnen) adlı anıt da hiçlik meselesiyle ilgilenir. Yine karşı-anıt türündeki bu eser, aslen Sigmund Aschrott isimli bir Alman Yahudisi'nin 1908'de şehir meydanında inşa ettirdiği ve Nazilerin 1939'da yıktığı çeşmenin, negatif bir formla yeniden yaratımıdır. Hoheisel'ın çeşmesi, Aschrott'unkinin aksine yerin altında ters olarak durmakta ve üzeri camla kaplı vaziyette, tıpkı bir ayna gibi geçmişi yansıtmaktadır. Sanatçı, böyle kamusal bir alanda, sanki yerin içinde açık bir yara ve soru gibi durmakta olan bu anıtla, Kassel vatandaşlarına doğrudan seslenerek, bu tür trajedilerin bir daha asla yaşanmaması için onları düşünmeye davet etmektedir (Young, 1992, ss. 288-294).

Görsel 9. Horst Hoheisel, "Aschrott Çeşmesi, Kassel (Kaynak:https://xpandsite.wordpress.com/hoheisel-aschrottbrunnen-kassel-1985/)

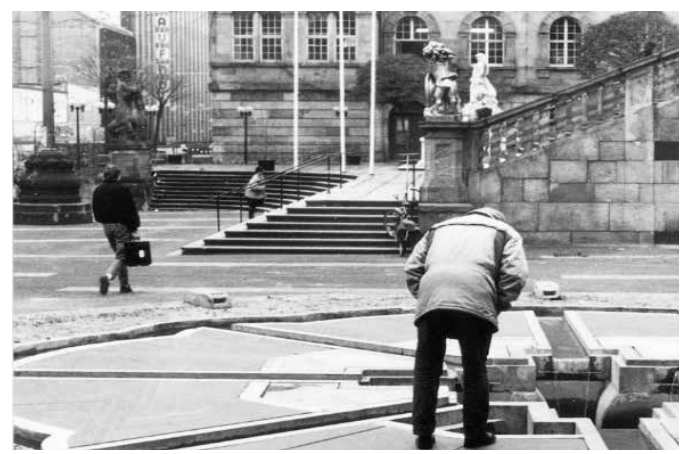


Eserlerin mekânlarla ve bu mekânları var eden insanlarla yakalamaya gayret ettiği ilişkisellik, görüldügü üzere anlamayı ve hatta sorumluluk almayı talep eden bir özellik gösterir. Tıpkı Levinas'ın öteki ile ilişkiyi ele alışında olduğu gibi, "ben" burada "başkadan" sonsuzca sorumlu (2010, s. 123) olarak düşünülmektedir. Ve sorumluluktan kaçmak, her zaman, şiddetin çıkış noktası olagelmiştir. Bu açıdan, başka bir uygun örnek de, Arjantin'in başkenti Buenos Aires'te devlet terörü mağdurları için yapılan "Hafıza Parkı" ve bu alan içinde bulunan, sanatçı Nicolás Guagnini'nin "30.000" ismindeki anıttır. 23,5 Hrant Dink Hafıza Mekânı'nın hazırlık sürecinde tüm dünyadaki hafıza mekânlarını ve müzeleri ziyaret ederek yaptığı saha çalışmasının raporunda ${ }^{11}$ belirtildiği gibi, sanatçı bu anıtı, askeri cunta tarafından kaybedilen babasına ithaf ederek yapmıştır. Dikkat çekici nokta ise, eseri oluşturan 25 adet çelik sütunun etrafında dolaşanların belli bir açıdan Guagnini'nin babasının portresini görebiliyor olmalarıdır. Bu görüntü, şaşırtıcı bir biçimde tam yakalandığı noktadan uzaklaşıldıkça silikleşmeye ve belli bir yerden sonra tamamen beyaza bürünmektedir. Böylelikle, yine raporda da söylediği üzere, kaybolma, yok olma, meydana çıkma ve görünme kavramlarını sorgulayan anıt, farklı açılardan bakıldığında hakikatin değişkenlik gösterebileceğini anlatmak istemektedir.

Görsel 10. Nicolás Guagnini, "30.000”, Buenos Aires (Kaynak: https://parquedelamemoria.org.ar/30-000/)

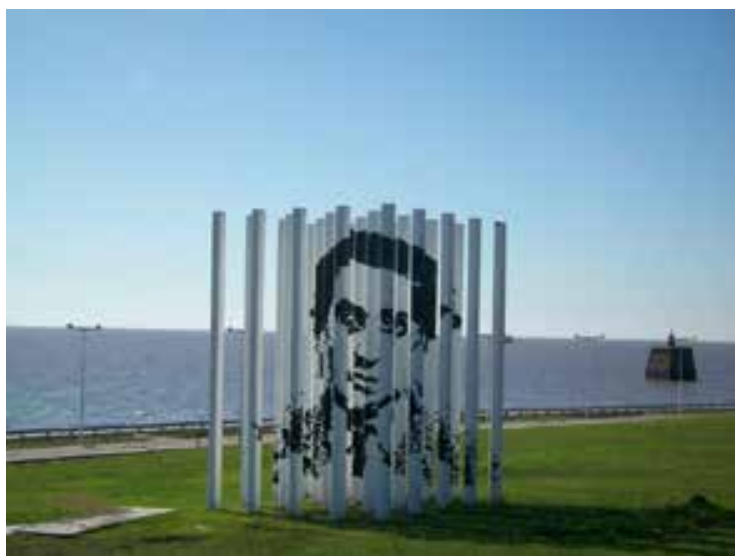

Müzeler ve anıtlar haricinde, yine bir grup insanın girişimiyle sonradan hafıza mekânı olan çokça eski yaşam alanı vardır. Bunlar eski sinemalar, okullar ve hatta ailelerin yaşadığı ev ve apartmanlar gibi resmi ve gayri resmi nitelikteki yerler de olabilirler. Lübnan'ın başkenti Beyrut'taki Beit Beirut Binası (diğer adıyla Barakat Binası) tam da böyle bir hafıza mekânıdır. 1975 ile 1990 yılları arasında gerçekleşen Lübnan İç Savaşı'nın derin izlerini taşır. Yapının muhafaza edilmesine ve bugünkü işlevine kavuşmasına öncülük eden mimar, küratör ve

11 23,5 Hrant Dink Hafıza Mekânı, Hazırlık Süreci Raporu, 2018, HDV Yayınları. 
aktivist Mona El Hallak'ın anlattıklarına ${ }^{12}$ bakılırsa, 1924 senesinde Youssef Aftimus tarafından yapılan bina, savaşa kadar pek çok aileye ev sahipliği yapmış. Aynı zamanda, bir dişçi kliniği ve bir fotoğraf stüdyosunun da bulunduğu yapının sakinleri, bombardımanlar başlayınca burayı terk etmek zorunda kalmışlar. Çatışmaların yoğun yaşandığı iki ana caddenin kesişiminde durduğu için, hem konumu hem de mimarisinin elverişliliği gereği, keskin nişancıların karargâhı olarak kullanıır olmuş.

Mona El Hallak, bu mekânı, savaşın bitiminden dört yıl sonra, bir hayalet şehre dönmüş Beyrut'taki yürüyüşleri sırasında keşfetmiş ve en başta mimarisine hayran kalmış. Onca hasara rağmen sık kirişleri sayesinde ayakta duran ve farklı bölümleri yine bu kirişlerle ve köprülerle birbirine bağlanan eşsiz yapı, El Hallak'a, ikiye bölünen ama yeniden bir araya gelerek yaralarını sarması gereken Lübnan'ın bir metaforu gibi gelmiş. Burasının herkes için bir umut ve hafıza mekânı olabileceğine inanmış. Bu nedenle "Şiddet nasıl hatırlanabilir ve hatırlama yoluyla bir daha tekrarlanmamak üzere unutulabilir mi? Beyrut gibi 15 sene bir iç savaş yaşamış ve 28 yıl boyunca savaş sonrası hafıza kaybını yaşamış bir şehirde hatırlamayı nasıl gerçekleştirebiliriz?" sorularıyla yola çıkarak, hafızalaştırma çalışmalarına başlamış.

Bu süreçte çıkan yıkım kararına karşı giriştiği mücadeleyi de kazanan El Hallak, Beyrut Belediyesi'ni Paris Belediyesi ile ortak bir rehabilitasyon projesi yapmaya ikna edince, bina beş yıllık bir çalışmanın ardından tüm izleriyle korunarak, iç savaşı kabul eden ve tanıyan ilk kamu binası olma özelliğini kazanmış. Keskin nişancıların kullandığı açıklardan içeri giren gün ışığıyla ve her hafıza katmanıyla kendisi bir sanat yapıtı olan bu mekân, hem mağdurlara hem faillere, savaşın insanları ve şehri nasıl değiştirdiğini fakat bunun yanında bombalar inerken nasıl hayatta kalabildiklerini ve direnişlerini hatırlatmaktadır. Diğer yandan, binanın içinde buldukları türlü belge ve fotoğraflar ise, savaştan önceki Beyrut hakkında unutulanları ortaya çıkarmış. Örneğin, her şeyin yerli yerinde durduğu diş doktorunun muayenehanesinde klinik aletler ve hasta kayıtlarıyla birlikte savaşta yok edilmiş sinemaların film broşürleri ve biletleri de bulununca, ne kadar önemli bir arşivle karşılaştıklarını anlamışlar.

Bir başka önemli kaynak da, binadaki Foto-Mario ismindeki fotoğraf stüdyosunda bulunan büyük bir fotoğraf ve negatif arşivi olmuş. Ne var ki savaş sonrası yeniden yapılanmayla ilgili sorunlar nedeniyle bu arşivin sergilenmesi ancak 2017 senesinde mümkün olabilmiş. Yoğun uğraşların ardından nihayet binanın zemin katında açılan kalıcı sergi, büyük bir çekim alanı yaratmış. Öyle ki yoldan geçip gidenlerin dahi içeri sorularla girmesini ve şehrin savaştan önceki hayatını merak etmelerini sağlamış. Aradan geçen zaman içinde ise, insanların kendilerine ya da aile mensuplarına fotoğrafları ve negatifleri gelip keşfettiği ve

12 Hrant Dink Vakfı tarafından, DVV International ve Friedrich-Ebert Stiftung iş birliğinde düzenlenen "Başka bir Gelecek için Hafıza Mekânları, Hafıza Yolları" başlıklı uluslararası konferansta, Mona El Hallak'ın "Hatırlayış ve Unutma Arasında Beyrut" isimli konuşmasından alınmıştır (22.03.2019, Yapı Kredi Kültür Sanat Loca) 
hikâyelerini anlattığı dinamik bir hatırlama mekânına dönüşmüş. Onların yaptığı katkılarla, Beyrut'un neredeyse büsbütün silinmiş olan belleğini adeta bir arkeolojik kazı yapar gibi meydana çıkarmış. Bu ortak çaba, El Hallak'a göre, sadece savaşı yaşamış kimseler için değil, savaştan sonra doğmuş kuşaklar için de geçmişle kopan bağı iyileştirme yolunda önemli bir adım olmuş. Çünkü savaştan sonraki hafıza kaybına dikkat çekmek, aynı zamanda diyaloğun ve umudun da altını çizmek anlamına gelir. Hikâyelerin anlatılıp paylaşılması bu noktada, El Hallak'ın deyişiyle, geleceğe yön verebilecek ve Lübnanlıları ön yargısız birbirlerine bağlayabilecek en mühim unsurdur.

Görsel 11. Beit Beirut Binası, dış cephe

Görsel 12. Beit

Beirut, Fotoğraf Galerisi

(Kaynak: https://www.admiddleeast.com/architecture-interiors/ architecture/beirut-war-era-building-gets-reclaimed-as-honorarymuseum, http://runway27l.co.uk/2018/10/12/beit-beirut-and-thebuildings-of-war/)
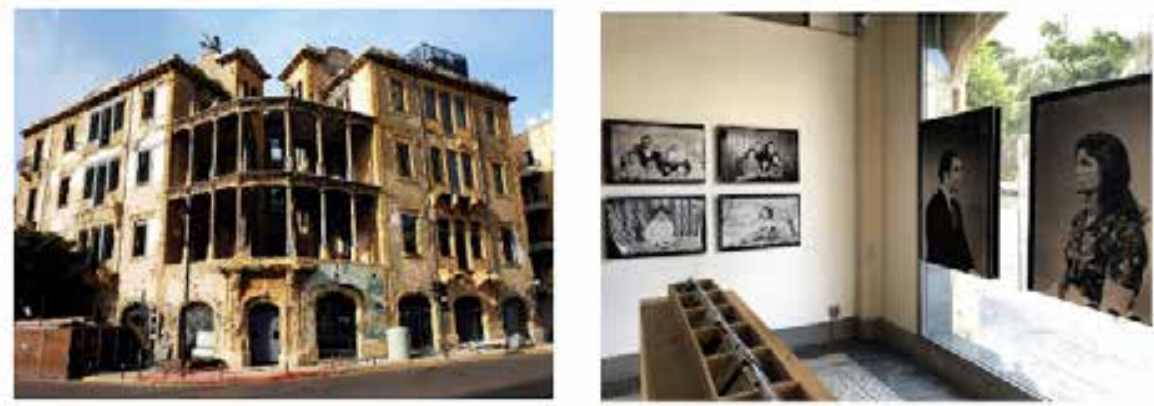

Konumuzla ilgili ele alacağımız son örnek ise, Hrant Dink Vakfı bünyesinde kurulan 23,5 Hrant Dink Hafıza Mekânı. Türkiye'de bir hafıza mekânı olarak açılan ilk yer olması, Türkiye'nin zor geçmişlerle yüzleşme konusundaki eksikliğine ya da hafızanın iyileştirici gücü konusunda farkındalık yaratan çalışmaların yaygınlık kazanmasının gerekliliğine dair çok şey söylerken, biz bu mekânı anlayabilmek için öncelikle ortaya çıkışının tarihsel, toplumsal ve politik arka planına ve bir hafıza mekânı olma yolundaki yapılanma sürecine eğileceğiz.

Bilindiği gibi, Agos Gazetesi Genel Yayın Yönetmeni Hrant Dink'in 19 Ocak 2007'de gazete ofisinin bulunduğu İstanbul Şişli'deki Sebat Apartmanı'nın önünde uğradığı silahlı saldırı sonucu hayatını kaybetmesi, yarattığı sarsıcı etkiyle, bugün hâlâ devam etmekte olan bir adalet arayışının ve unutmaya karşı hafızıyla direnişin başlangıcı olmuştur. Farklı kesimlerden pek çok insanın vicdani bir tepkiyle karşıladığı bu trajedi, 2007'den bu yana, her 19 Ocak'ta Hrant Dink'in öldürüldüğü noktada, onu anmak üzere yüzlerce kişiyi bir araya getirmektedir. 
Adını Hrant Dink'in "23,5 Nisan"13" başıkılı bir yazısından alan hafıza mekânı da, onun insan hakları, toplumsal eşitlik ve barışa dair, ölümüne dek savunduğu fikirlerini ve mücadelesini sürdürmek amacıyla 2007'de kurulan Hrant Dink Vakfı'nın içinden doğmuştur. Çalışmalarına, 2015 senesine kadar Sebat Apartmanı'nda devam eden vakıf ve gazete, yıllar içinde büyüyen kadro ve çeşitlenen projeler nedeniyle buradan taşınmak durumunda kalınca, toplum nezdinde sembolik bir anlam kazanmış olan bu yerin de bir hafıza mekânına dönüştürülmesine karar verilmiş ${ }^{14}$ Temel olarak; ayrımcılığın ve nefretin her türlüsüne karşı eşitliği, empatiyi ve toplumlar arası diyaloğu teşvik eden bir girişimle ve dört seneye yayılan yoğun bir araştırma ve hazırlık süreci sonrasında, 17 Haziran 2019'da açılan mekân, insanlık trajedilerinin üstesinden gelebilmenin ancak unutmanın karşısına hatırlamayı ve umudu koyarak mümkün olabileceğini geniş kitlelere anlatma gayesini taşımaktadır.

Mekânın hazırlık aşamasında farklı coğrafyalardaki örnekleri inceleyebilmek için, on beş ülkede seksenin üzerinde hafıza mekânının ziyaret edilmesi, alandaki uzmanlarla birebir görüşmeler yapılması ve gidilen uluslararası panellerdeki bilgi ve deneyim alışverişleri, kurulacak olan mekânın içeriğine, anlatımına, işlevlerine ve tasarımına dair fikirler geliştirilmesine olanak sağlamış. Bunların yanında, mekânın yapılanma sürecinde gerçek anlamda katıımcı bir yaklaşımla hareket edilerek; sergi tasarımı ve söylemi konusunda hem ziyaretler ve paneller sırasında tanışılan uzmanların hem de periyodik olarak düzenlenen diyalog toplantılarında farklı disiplinlerden ve yaş gruplardan bireylerin deneyim, fikir ve önerilerine başvurulmuş. ${ }^{15}$

Tüm bu aşamaların ardından hayata geçirilen 23,5 Hrant Dink Hafıza Mekânı, bulunduğu 145 metrekarelik alan içinde, ziyaretçilerini görsel, işitsel ve dokunsal deneyimler yoluyla geçmişi anlamaya, düşünmeye, öğrenmeye ve öğrendiğini tartışıp yorumlamaya davet eden bir mekâna dönüşmüştür. Buraya girişteki ilk anlardan itibaren, adalet, kimlik ve hakikat konularına işaret eden sorularla açılan videolar, ziyaretçiyi merakı teşvik eden bir anlatının içine çekmektedir. Hrant Dink'in konuşmalarını da içeren videoların yanı sıra, bu anlatı mekân boyunca, fotoğraflarla, yazılı belgelerle, çeşitli enstalasyonlar ve çizimlerle desteklenmektedir. Örneğin; Agos yazılarıyla, manşetleriyle ve görselleriyle kaplanmış olan "Koridor Odası", 1996 ve 2007 yılları arasından tarihsel bir panorama sunan duvarlarıyla, azınlık toplumlarına ilişkin önemli olayları ve haberleri göstermektedir. Buradaki anlatının zamansal bütünlüğü, koridora açılan odalarda sergilenenler de zenginleşir.

13 http://www.agos.com.tr/tr/yazi/22350/23-5-nisan

14 23,5 Hrant Dink Hafıza Mekânı'nda 25.10.2019 tarihinde düzenlenen 'Hafıza Mekânları Atölyesi'den edinilen bilgi. Ayrıca, 23,5 Hrant Dink Hafıza Mekânı Hazırlık Süreci Raporu, sf.21, 2018, HDV Yayınları.

15 23,5 Hrant Dink Hafıza Mekânı Hazırık Süreci Raporu, sf.23-25, 2018, HDV Yayınları. 
Görsel 13 ve 14. 23,5 Hrant Dink Hafıza Mekânı Giriş ve "Koridor Odası" (Fotoğraf: CAcun)
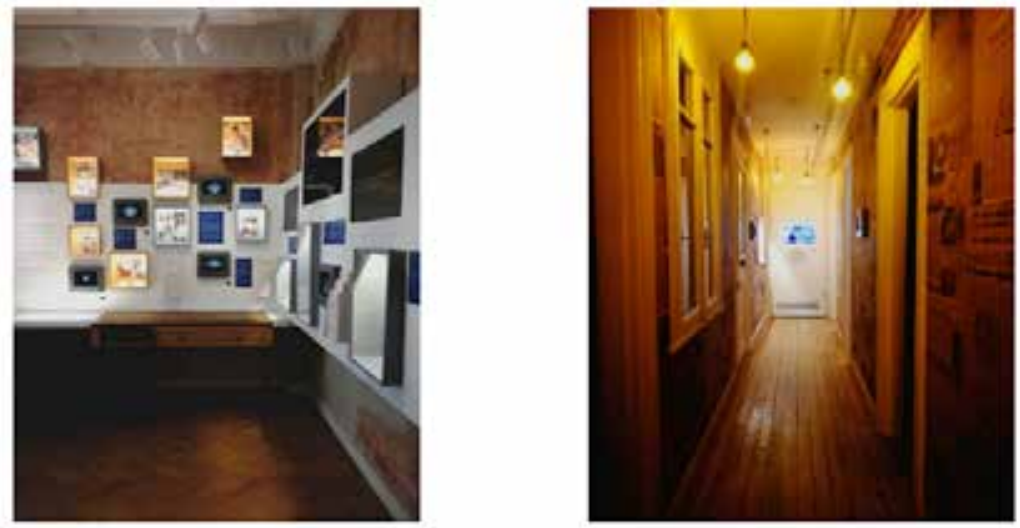

"Tırttava Odası" da bu odalardan biridir. Ermeni kimliğinden ötürü askerlikte erbaşlığa yükseltilmemiş olan Hrant Dink, çok içerlediği bu ayrımcılık karşısında gizlice ağlarken bir yandan sesi duyulmasın diye elindeki anahtarlığı teneke bir barakaya sürter. Odanın ismi, tenekeden çıkan bu sesi çağrıştıır. Hikâyenin, Dink'in video tanıklığı üzerinden aktarılmasının yanında, bir de tüm odanın anlatılan teneke baraka formunda bir enstelasyon olarak tasarlanmış olması, ziyaretçinin empatik bir deneyim yaşamasına olanak sağlamaktadır. Odanın bir başka özelliği de, interaktif bir video kaydetme ve izleme aracıı̆ğıla ziyaretçilerin kendi başlarından geçen ayrımcılık hikâyelerini paylaşmalarına ve başka ziyaretçiler tarafından kaydedilmiş videoları da izleyebilmelerine imkân vermesi.

Görsel 15. "Tırttava Odası" (Fotoğraf: C. Acun)

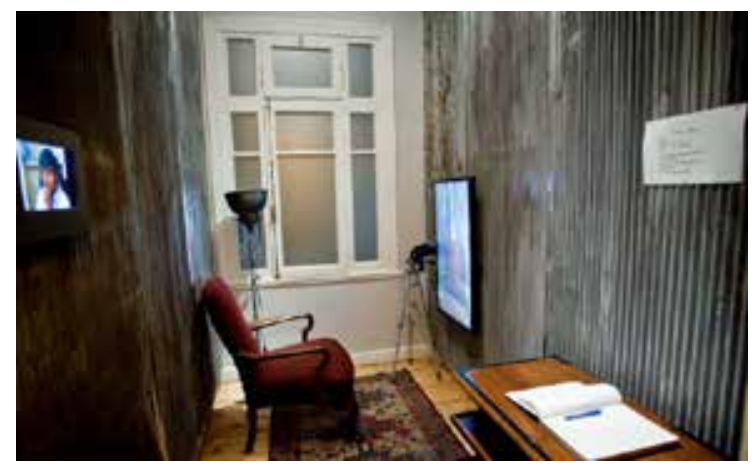

Esasında hafıza merkezindeki en dikkat çekici nokta, Hrant Dink'in bir anlatıcı olarak tüm odaları bizimle birlikte dolaşmasıdır. Tırttava Odası'nda olduğu gibi, gerek videolar ve fotoğraflarla gerekse de kişisel eşyalarıyla. 1980 Darbesi'nde gözaltına 
alındığında tutulduğu tuvaletten bozma hücrede yaşadığı işkenceleri anlatarak bu kaotik döneme dair gerçeklere ışık tuttuğu "Tuvalet Korosu" ismindeki odada veya Tuzla'daki Kamp Armen'de geçen çocukluğunu, eşi Rakel Dink ile tanışmasını ve burayı yaşatmak için verdiği mücadeleyi anlattığı "Atlantis Uygarlığı" isimli odada da aynı durum geçerlidir. Ziyaretçiler, olayları onun gözünden öğrenirler. Dolayısıyla, bu etkileşimsel ortam ziyaretçileri de tanıklar olarak konumlandııır.

Görsel 16. "Atlantis Uygarlı̆̆ı Odası" (Fotoğraf: C. Acun)

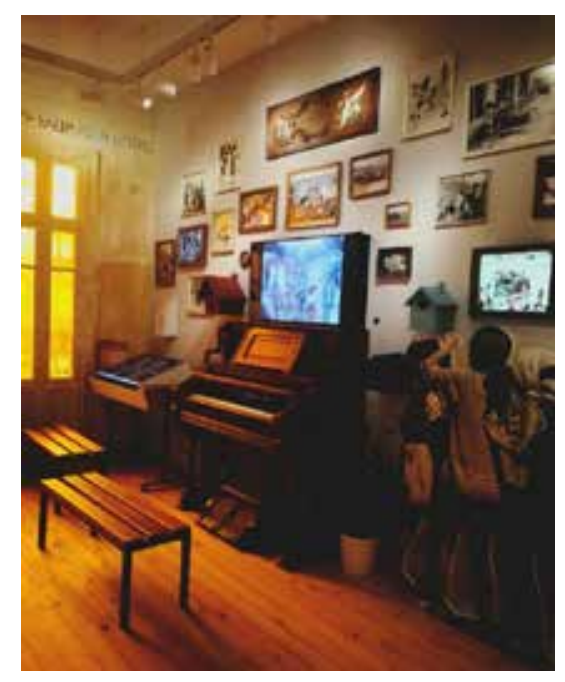

Mekânın en arka tarafında bulunan Hrant Dink'in çalışma odasında da aynı deneyim yaşanır. 19 Ocak 2007'den bu yana aynı haliyle muhafaza edilen odada, masası, sandalyesi, defterleri, kitapları, asklıktaki ceketi, Anadolu'nun farkıı köşelerine yaptığı ziyaretlerden topladığı bazı resimler ve küçük heykeller en son bıraktığı gibi durmaktadır. Ziyaretçilerin bu eşyalara dokunmasına izin verildiği için (sözgelimi, kitaplığın raflarındaki kitaplardan birini alıp bakmak mümkün), bu fiziksel temas sayesinde odanın canlı ve nefes alıp veren bir yer olmaya devam ettiğini söylemek mümkün. Odanın balkonunda ise sanatçı Sarkis'in bu mekân için tasarladığı "Tuz ve ışık" adlı enstalasyonu yer almaktadır. "Acılardan pırlanta yaratma" metaforundan yola çıkan sanatçı, yaptığı bu çalışma ile ilgili şu sözleri dile getirmiş:

"Burası için aylarca çalıştık, en sade şekilde ışıklarla donattık burayı, bütün bu camlar elle yapıldı, kırmızı sıcaklığı, büyük duyguları dile getiriyor, mavi büyük bir sükûneti, bütün dünyamızı temsil ediyor. Burada kandil yanıyor olacak hep ortada. Hrant'ın odasından çıkan adakları gümüş çivilerle astık duvarlara. İsteyen de adaklarını asabilecek buraya..." 16

16 https://m.bianet.org/bianet/azinliklar/207744-23-5-hrant-dink-hafiza-mekani-turkiye-unutmasin-bundan-sonra-diye 
Sarkis, burada sürekli yanan kandilin tam üstündeki tavana da Kamp Armen'in krokisinin neon ışıkla temsil edildiği bir ışık yerleştirmiş.

Görsel 17. Hrant Dink'in Çalışma Odası Görsel 18. Sarkis, "Tuz ve Işı"", 2019 (Fotoğraf: C. Acun)
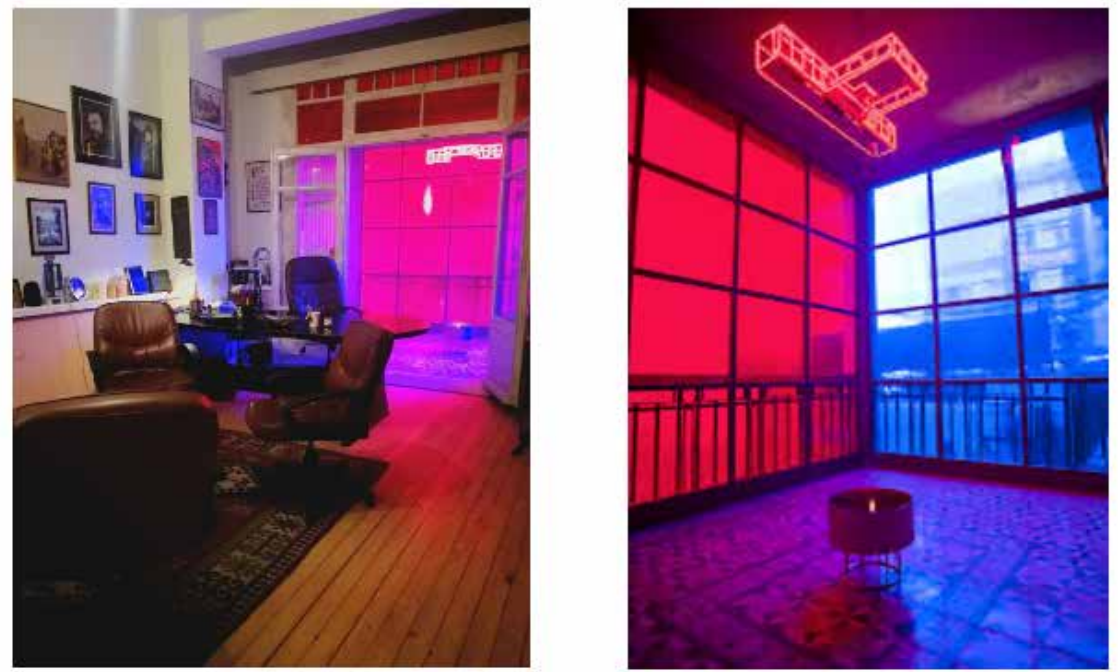

23,5 Hrant Dink Hafıza Mekânı'nında sürekli sergilenecek olan diğer sanat yapıtı da, yazıda daha önce Yahudi Soykırımı'na dair karşı anıt türündeki çalışmalarına yer verdiğimiz Horst Hoheisel ve Andreas Knitz'in Türkiye-Ermenistan ilişkilerine atfen yaptıkları "Büyükelçilik Kurma Projesi". Büyükelçilik levhasıymışçasına tasarlanan ve bir tarafı Ermenice, diğer tarafı Türkçe olan metal levhalardan oluşan çalışma, mekânın giriş bölümünde duvara asılı olarak durmaktadır. İlk olarak Hrant Dink Vakfı'nın davetiyle ${ }^{17}$ bu projeye başlayan sanatçılar, iki ülke arasında "hiç olmayan" bir diplomatik ilişkiye dikkat çekmek istemişler. Bunun için 2017'de vakıftan da küçük bir ekibin katılımıyla, hep birlikte Ermenistan'a seyahat ederek, burada gittikleri her yere ve uğradıkları her kafe ve lokantaya bu levhalardan bırakarak, buraları büyükelçilik ilan etmişler. Böylelikle, ülkeler arasında barışın sağlanmasının gerekliliğini ve bir araya gelmenin hiç de imkânsız olmadığı gerçeğini anlatmaya çalışmışlar.

Sanatla öğrenme deneyimini ön plana alan yukarıda değindiğimiz diğer hafıza mekânlarında olduğu gibi, 23,5 Hrant Dink Hafıza Mekânı'nda da sunulan duyusal deneyimlerin yanında, keşfettirmeye ve araştırmaya olanak sağlayan, yara-

17 Hrant Dink Vakfı tarafından, DVV International ve Friedrich-Ebert Stiftung ișbirliğinde düzenlenen "Başka bir Gelecek için Hafıza Mekânları, Hafıza Yolları" başıkılı uluslararası konferansta, Andreas Knitz'in "Bir Elçilik Olarak Sanat" isimli konuşmasından alınmıştır (22.03.2019, Yapı Kredi Kültür Sanat Loca) 
tıcı bir eğitim anlayışıyla düzenlenen atölyelere ve yenilikçi ziyaretçi programlarına önem verilmektedir. Örneğin, periyodik olarak gerçekleşen "Hafıza Arkeolojisi" isimli atölye çalışması, nesneler üzerinden kurulan anlatılarla geçmiş, şimdi ve geleceğin birbirleriyle nasıl ilişkilendiğine odaklanırken, "Hafıza Mekânları Atölyesi", katıımcılarına hafıza mekânlarının ne gibi işlevlere sahip olduğunu, hatırlamanın niçin gerekli olduğunu ya da trajedilerin umuda ve direnişe nasıl evrilebileceğini anlatmayı hedefler. Karşılıklı anlayışın ve geçmişle yüzleşmenin önemini gündeme getirerek bu meselelere katkı yapmaya çalışan diğer etkinliklerle beraber, erişime açık tutulan arşiv sayesinde ise, burasının aynı zamanda bir soru sorma, araştırma ve düşünme mekânı olması amaçlanmıştır.

\section{Sonuç: Acının Tapınaklarından Umudun ve Öğrenmenin Mekânlarına}

Susan Sontag, 2000'li yılların başında kaleme aldığı Başkalarının Acısına Bakmak adlı denemesinde, o sıralarda hızla çoğalmakta olan hafıza müzelerini, Yahudi Soykırımı Müzeleri örnekleri üzerinden ele alarak, bu mekânların, Avrupalı Yahudilere yönelik imha kampanyası hakkında düşünme ve yas tutma biçimlerinin ürünleri olarak ortaya çıktıklarını söyler. Kuruluş amaçları gereği, insanlarda kendi hafızalarını durmadan yoklama ve tazeleme isteği uyandırmaları nedeniyle de, bu müzelerin aynı zamanda başka trajedilerin kurbanı olmuş halkları da kendi müzelerini açmaya sevk ettiğini belirtir. Bu gözlemleri neticesinde hafıza müzelerini, "acıların kapsamlı, kronolojik biçimde düzenlenmiş ve fotoğraflarla beslenmiş bir anlatıya sığınak olduğu tapınaklar" (2005, ss. 87-88) olarak nitelendirir.

Sontag'ın bu değerlendirmesi üzerinde düşündügümüzde, hafıza müzeleri, daha çok acı üzerinden bir duygudaşlık yaratan ve hatta "acıyı yücelten" yerler olarak ön plana çıkarlar. Aynı şekilde, bir hafıza mekânı ya da müze kurma girişiminde bulunan halklar yalnızca "kurban" kimlikleriyle bir ölümsüzlük mertebesi talep eden kimseler olarak konumlandırılırlar. Özetle, bu bakış açısı çoğu bakımdan, hem hafızanın hem de hafıza mekânlarının sahip olduğu dönüştürücü potansiyeli görmekten uzaktır. Yazıda üzerinde durduğumuz gibi, hafızanın hakikatlerin aydınlatımasındaki itici gücü, en mühim direniş aracıdır. Dolayısıyla, dünyanın birçok yerinde, ötekileştirilen topluluklar en temel yaşam haklarını kazanabilmek ve unutulmuş kimi haksızlıklarla başa çıkabilmek için hafıza mekânları kurma girişiminde bulunmaktadır. Üstelik, bu girişimleri başlatanlar, geçmişin acılarına tutunan "kurbanlar" değil, umut etmeyi rehber edinerek bir gelecek tasavvuru yaratmaya çalışan "aktörlerdir".

Anlaşılma ve görünür olma ihtiyacından doğan bu mekânlar, mümkün olduğunca iletişimi teşvik eden yerlerdir. Bu nedenle kendilerine gereken ifade alanını sağlayabilmek için, en başta sanat gibi güçlü bir mecraya başvurarak, Bourriaud'nun da söylediği gibi, onun bireysel ya da toplu buluşmalara zemin hazırlayan ilişkisel yapısından faydalanırlar. Sunulmak istenen anlatı, duyusal deneyimi elverişli kılan sergilenme biçimleriyle desteklenirken, ziyaretçilerin de bu anlatıların pasif alımlayıcıları olarak değil, aktif yorumlayıııları olmaları hedeflenir. Söz konu- 
su katılımın olabilmesi içinse, Sontag'ın bahsettiği türden, salt acı üzerine temellenen bir duygudaşlık ya da acıma hissi yerine, Landsberg'in vurguladığı anlamda etik düşünmeyi, tefekkürü mümkün kılacak bir empati bağının kurulması gerekir. Işte sanat gibi protez bir bellek aracıyla sağlanan bir iletişim ve öğrenme alanı bu yüzden de önemlidir; empati üzerine temellenir, zor geçmişlerle başa çıkabilme yollarını yaratıcı yollarla gösterir.

Her anma alanı gibi hafıza mekânları da, tıpkı Robert Musil'in anıtlar için söylediği üzere, bir süre sonra oluşan göz aşinalığı nedeniyle, "görünmezleşme tehlikesi" (1986, s. 320) taşırlar. Musil'in sözleri daha çok geleneksel tipte, devlet ideolojileri çerçevesinde yapılmış ve dolayısıyla soru sordurmak gibi bir gayesi olmayan anıtlara yöneliktir. Ancak yine de tam da bu risk nedeniyle; geçmişte yapılmış hataların, işlenmiş suçların bir daha tekrar etmemesi için çabalayan hafıza mekânlarının da, tıpkı yukarıda yer verdiğimiz örneklerde olduğu gibi, merak uyandıracak tasarımlardan, katıımcı, etkileşimsel yollardan vazgeçmemesi; sanatın ilişkisel alanından beslenerek yeni öğrenme yöntemleri ve hatırlama pratikleri üretmesi mühimdir.

\section{Kaynakça}

Anderson, B. (1995). Hayali Cemaatler. İ. Savaşır (Çev.). İstanbul: Metis Yayınları. Assmann, A. (2008). "Canon and Archive". Media and Cultural Memory içinde (s.97-107) ed. A. Erll ve A. Nünning. Berlin: Walter de Gruyter.

Assmann, A., Conrad, S. (2010). "Introduction". Memory in a Global Age içinde (s.1-16) ed. A. Assmann ve S. Conrad. London: Palgrave MacMillan.

Assmann, A. (2012). "To Remember or to Forget: Which Way Out of a Shared History of Violence?". Memory and Political Change içinde (s.53-71) ed. A. Assman ve L. Shortt. London: Palgrave Macmillan.

Appadurai, A. (2013). The Social Life of Things. Cambridge University Press.

Borges, H. L. (2013). Ficciones: Hayaller ve Hikâyeler. F. Özgüven ve T. Uyar (Çev.). İstanbul: Illetişim Yayınları.

Bourriaud, N. (2005). İlişkisel Estetik. S. Özen (Çev.). İstanbul: Bağlam Yayınları.

Cassirer, E. (1980). İnsan Üstüne Bir Deneme. N. Arat (Çev.). İstanbul: Remzi Kitabevi.

De Certeau, M. (2009). Gündelik Hayatın Keşfi I. L. A. Özcan (Çev.). Ankara: Dost Kitabevi.

Foucault, M. (1975). Film in Popular Memory: An Interview with Michel Foucault. Radical Philosophy içinde. (s.24-29). 11 (11).

Foucault, M. (1977). Nietzsche, Genealogy, History. Language, Counter-Memory and Practice içinde. New York: Cornell University Press. 
Gibbons, J. (2007). Contemporary Art and Memory. London: I.B.Tauris.

Halbwachs, M. (2018). Kolektif Bellek. Z. Karagöz (Çev.). İstanbul: Pinhan Yayıncılık. Hansen-Glücklich, J. (2014). Holocaust Memory Reframed. New Jersey: Rutgers University Press.

Hirsch, M. (1997). Family Frames: Photography, Narrative and Postmemory. Harvard University Press.

Hirsch, M. (2012). The Generation of Postmemory: Writing and Visual Culture After The Holocaust. New York: Columbia University Press.

Huyssen, A. (1999). Alacakaranlık Anıları. K. Atakay (Çev.). İstanbul: Metis Yayınları. Landsberg, A. (2004). Prosthetic Culture. New York: Columbia University Press.

Levinas, E. (2010). Sonsuza Tanıklık. Z. Direk, E. Gökyaran (Çev.). İstanbul: Metis Yayınları.

Marstine, J. (2006). New Museum Theory and Practice. Oxford: Blackwell Publishing. Megill, A. (2011). "History, Memory, Identity". The Collective Memory Reader içinde. Oxford University Press.

Musil, R. (1986). "Monuments". Selected Writings içinde (s.320-323) ed. Burton Pike. New York: Continuum.

Nora, P. (2006). Hafıza Mekânları. M. E. Özcan (Çev.). Ankara: Dost Kitabevi.

Orwell, G. (2011). 1984. C. Üster (Çev.). İstanbul: Can Yayınları.

Sancar, M. (2007). "Evrenselleşme Sürecindeki Geçmişle Hesaplaşma". Geçmişin Yükünden Toplumsal Barış ve Demokrasiye içinde (s.14-23) ed. U. Dufner. İstanbul: Heinrich Böll Stiftung.

Sontag, S. (2005). Başkalarının Acısına Bakmak. O. Akınhay (Çev.). İstanbul: Agora Kitaplığı.

Winter, J. (2012). "Remembrance as a Human Right". Memory and Political Change içinde (s.vii-xi) ed. A. Assman ve L. Shortt. London: Palgrave Macmillan.

Winter, J. (2015). "Tarihçiler ve Bellek Mekânları." Zihinde ve Kültürde Bellek içinde (s.321-343) Y. Aşçı Dalar (Çev.). ed. P. Boyer ve J. Wertsch. İstanbul: Türkiye İş Bankası Kültür Yayınları.

Young, J. (1992). "The Counter-Monument: Memory against Itself in Germany Today". Critical Inquiry içinde 18(2) (s.267-296).

Young, J. (2000). “Daniel Libeskind's Jewish Musuem in Berlin: The Uncanny Arts of Memorial Architecture". Jewish Social Studies içinde 6(2) (s.1-23). 